$$
\begin{aligned}
& \text { Report No. BMI-1348 } \\
& \begin{array}{l}
\text { UC-10 Chemistry - Separation } \\
\text { Processes for Plutonium and } \\
\text { Uranium (TID-4500, 14th Ed.) }
\end{array}
\end{aligned}
$$

Contract No. W-7405-eng-92

CONSTRUCTION MATERIALS FOR THE HYDROFLUORINATOR OF THE FLUORIDE-VOLATILITY PROCESS

\author{
by \\ Paul D. Miller \\ Charles L. Peterson \\ Oliver M. Stewart \\ Elmer F. Stephan \\ Frederick W. Fink
}

June 3, 1959

BATTELLE MEMORIAL INSTITUTE

$505 \mathrm{King}$ Avenue

Columbus 1, Ohio 


\section{DISCLAIMER}

This report was prepared as an account of work sponsored by an agency of the United States Government. Neither the United States Government nor any agency Thereof, nor any of their employees, makes any warranty, express or implied, or assumes any legal liability or responsibility for the accuracy, completeness, or usefulness of any information, apparatus, product, or process disclosed, or represents that its use would not infringe privately owned rights. Reference herein to any specific commercial product, process, or service by trade name, trademark, manufacturer, or otherwise does not necessarily constitute or imply its endorsement, recommendation, or favoring by the United States Government or any agency thereof. The views and opinions of authors expressed herein do not necessarily state or reflect those of the United States Government or any agency thereof. 


\section{DISCLAIMER}

Portions of this document may be illegible in electronic image products. Images are produced from the best available original document. 
ABSTRACT . . . . . . . . . . . . . . . . . . 1

INTRODUCTION .......................... . . . . . 1

EXPERIMENTAL WORK . . . . . . . . . . . . . . . . . 1

General Procedure . . . . . . . . . . . . . . . . . 1

Corrosion Results . . . . . . . . . . . . . . . . . 7

Inconel . . . . . . . . . . . . . . . . . 7

"A" Nickel . . . . . . . . . . . . . . . . . 14

Copper.......................... 14

Hastelloy $W$. . . . . . . . . . . . . . . . 14

Monel........................ 14

Silver ..................... . . . . . . 14

Hastelloy B........................ 17

INOR Alloys . . . . . . . . . . ........ 17

CONCLUSIONS . . . . . . . . . . . . . . . . . . . . 33

ACKNOW LEDGMENT . . . . . . . . . . . . . . . . . . 33

APPENDIX

SUMMARY OF CORROSION AND ANALYTICAL DATA . . . . . . . . . A-1 


\title{
CONSTRUCTION MATERIALS FOR THE HYDROFLUORINATOR OF THE FLUORIDE-VOLATILITY PROCESS
}

\author{
Paul D. Miller, Charles L. Peterson, Oliver M. Stewart, \\ Elmer F. Stephan, and Frederick W. Fink
}

Fuel elements clad with zirconium, or containing zirconium as a diluent, can be recovered by a fluoride-volatility process. The first step consists of hydrofluorination of the elements in a bath of molten fluoride salts using an HF sparge. In this case the two salt systems considered were $N a F-Z r F_{4}$ and $N a F-L i F$. Nine materials uere evaluated at Battelle for possible use in the construction of this hydrofluorinator: Inconel, "A"Nickel, copper, silver, Monel, Hastelloy B, Hastelloy W', INOR-1 and INOR-8. The metals were exposed to molten fluoride salts through which HF was bubbled continuously.

The data indicate that the $N a F-L i F$ systems are much more corrosive than the $\mathrm{NaF}-Z_{r F}$ system. The systems are most corrosive when the allali fluoride component is high. An elevation in temperature increases the corrosion significantly as does an increase in the HF flow rate. Hydrogen in the HF flow stream retards the corrosion of the sodium-zirconium salts significantly, but appears to have less effect on the sodium-lithium systems.

The areas at the interface of the liquid and vapor phases were most seriously damaged under the exposure conditions usually used. However, appreciable reduction in attach was experienced when zirconium was actually hydrofluorinated.

INOR-8 was the most promising of the materials evaluated.

\section{INTRODUCTION}

A considerable amount of development work has been done at ORNL and ANL on a fluoride-volatility process for recovering uranium from spent fuel. In the first step in this process, the fuel elements are dissolved by hydrofluorination in a molten fluoridesalt bath using an HF sparge.

As might be expected, the selection of container materials capable of withstand ing the corrosive attack of these operating conditions is an important part in the successful development of the process. An evaluation program for such materials was carried out as a program of assistance to the Chemical Technology Division of ORNL.

\section{EXPERIMENTAL WORK}

\section{General Procedure}

Candidate materials were evaluated under conditions simulating as nearly as possible those that might exist in an actual hydrofluorinator. Figure 1 is a schematic 


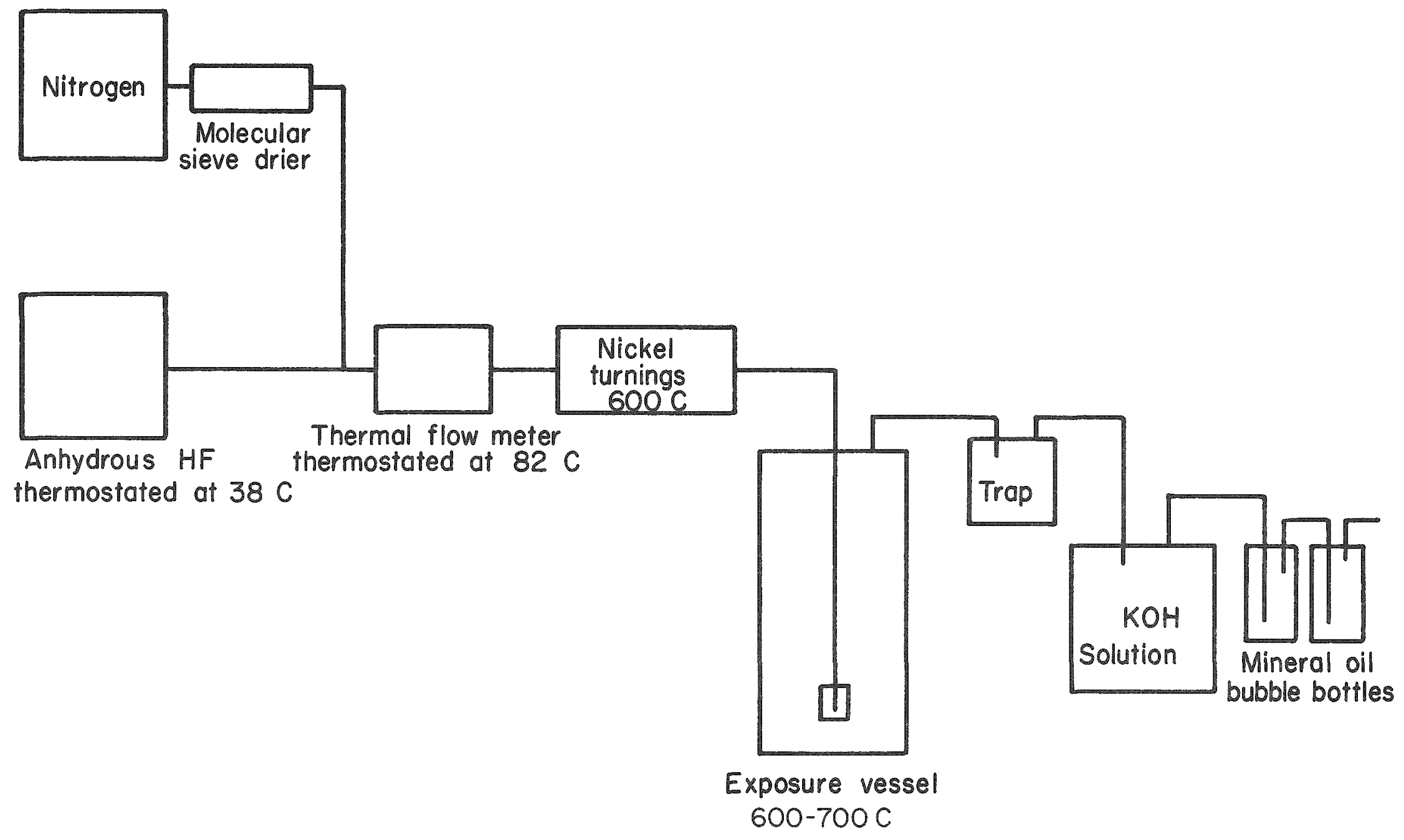

FIGURE 1. SCHEMATIC DIAGRAM OF CORROSION TEST ASSEMBLY 
diagram showing the arrangement of the apparatus used. The objective was to expose metals to molten fluoride salts at elevated temperatures while sparging with purified HF. The cylinder furnishing the gaseous HF was immersed in an oven thermostatted at $38 \mathrm{C}$. The oven and tank were placed on a platform balance so that HF consumption could be followed. Special thermal flowmeters, supplied by ORNL, were used to measure the gas flow. The flow was adjusted by a Hoke No. M343 Monel valve, which has a special 1 -deg taper at the closing cone. Both the valve and flowmeter were placed in a small oven maintained at $82 \mathrm{C}$.

The gas was passed through a nickel tube, about $3 / 4 \mathrm{in}$. in diameter and $18 \mathrm{in.}$. in length, filled with nickel turnings and heated to $600 \mathrm{C}$ in an attempt to scavenge sulfur compounds.

From the purification furnace, the gas was passed beneath the surface of the molten salt in the containers and allowed to bubble up past specimens inserted at various locations.

The effluent gas was passed through a copper trap and then through a battery of polyethylene bubble bottles containing mineral oil to prevent back-diffusion of air. Leaving the bubble bottles the gas was passed over the surface of an aqueous KOH solution held in a large ( 10 gal) polyethylene bottle, where it was largely absorbed. All inlet lines, external to the container assembly, were nickel. All valves were Monel. Effluent lines were copper or polyethylene. Thermocouples were Chromel-Alumel. Swagelok fittings permitted raising and lowering the thermocouples and sparge tube through the salt as desired. Two or three complete as emblies were usually available so that several experiments could be run simultaneously.

The first studies were made in Inconel containers furnished by ORNL. Figure 2 show the dimensions of these containers and the method used for mounting a single specimen. In these studies the specimens were cut into 2 -in. lengths from welded tubes made from the material being evaluated. They were mounted at the end of the sparge tube in such a manner that the gas bubbles would sweep over the inner surface of the tube. A slot cut in the end of the tube assured a fixed position at all times. These were called gas-impingement specimens.

Nine runs were made with these containers and it was apparent that enough "snow" (presumably ZrF4) was carried in the effluent stream to cause plugging of the lines at varying intervals. The containers were then modified by removing their top sections and welding on each a 12-in. length of Inconel pipe of the same diameter as the bottom. The top section was flanged, baffled, and water cooled. This arrangement eliminated carry-over of snow to the effluent lines and permitted operation for $1000 \mathrm{hr}$ at a time.

The preliminary studies showed that Inconel was appreciably attacked by the $\mathrm{Na} F-\mathrm{ZrF}_{4}$ system. Six new containers were then constructed from Hastelloy $B$, which other experience with fluoride salts indicated would be resistant to corrosion.

Figure 3 is a drawing giving the dimensions of such an assembly. Figure 4 is a photograph of an empty container and closure. The exit arm was packed with clean copper wool to trap any "snow" which might pass the baffle or cold wall of the container. The cylinder connected to the exit arm was made from copper and was placed in the circuit to trap the small amount of azeotropic $\mathrm{HF}-\mathrm{H}_{2} \mathrm{O}$ which usually formed. The nickel baffle 


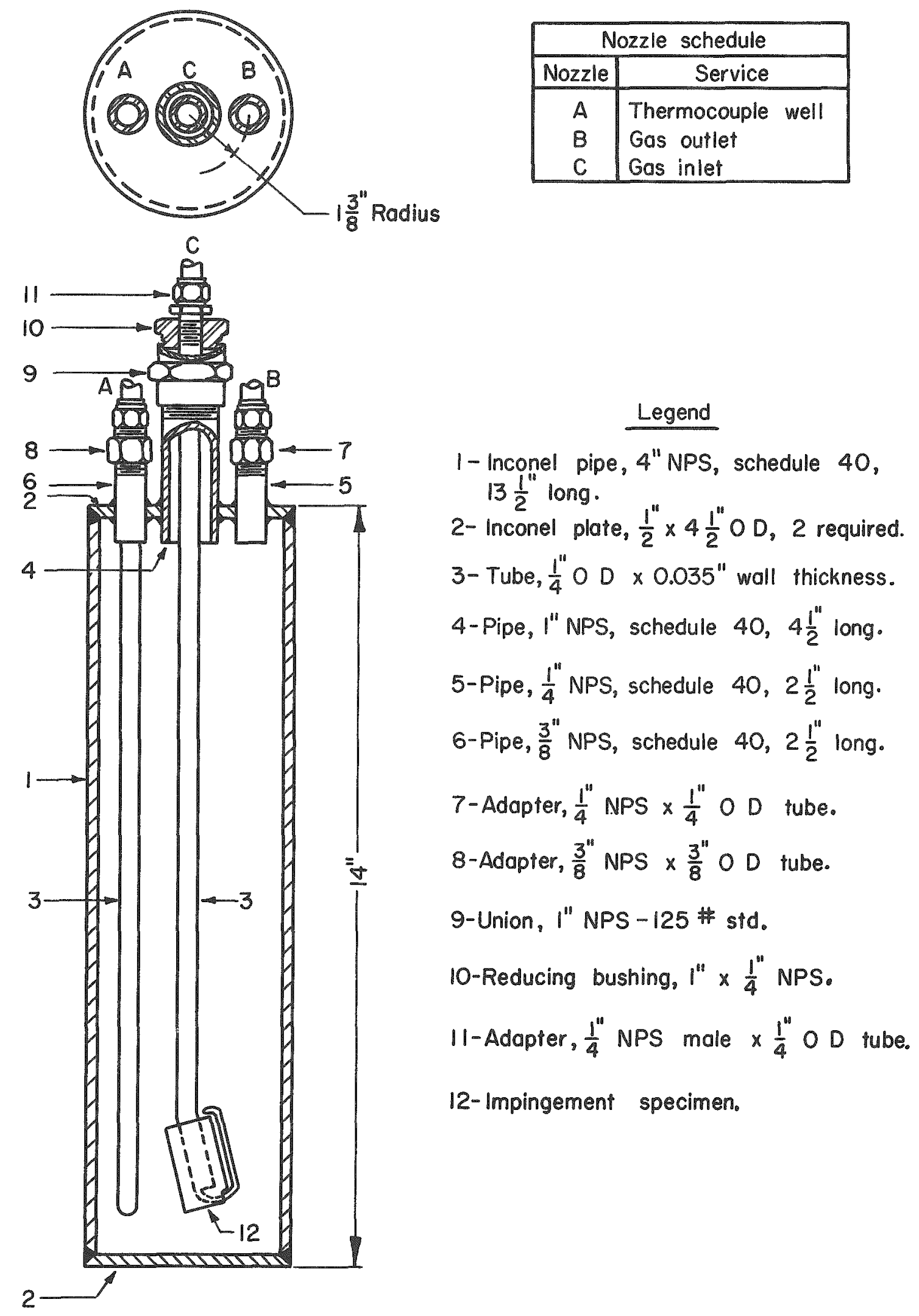

FIGURE 2. INCONEL-CONTAINER DESIGN AND METHOD FOR MOUNTING THE SPECIMEN 


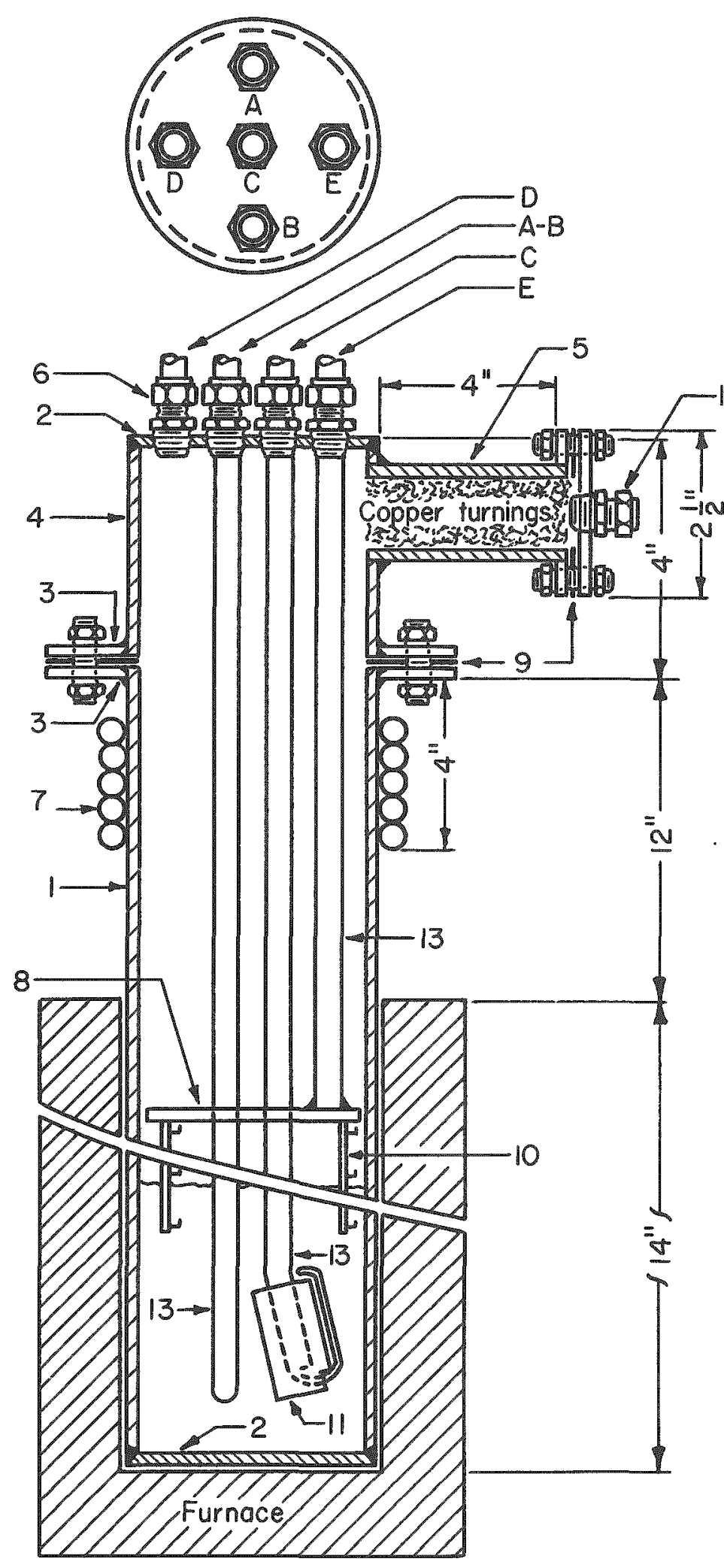

\begin{tabular}{|c|l|}
\hline \multicolumn{2}{|c|}{ Nozzle schedule } \\
\hline Nozzle & \multicolumn{1}{|c|}{ Service } \\
\hline A & Thermocouple \\
B & Thermocouple \\
C & Gas inlet \\
D & Pressure differential \\
& transmitter, and \\
E & emergency exhaust. \\
\hline
\end{tabular}

$2 \quad$ Legend

1- Hastelloy B pipe 4"NPS, schedule $10,26^{\prime \prime}$ long.

2- Hastelloy B plate $\frac{3^{11}}{8} \times 4 \frac{1}{2}^{11}$ $O D, 2$ required.

3- Hastelloy B plate (flange) $\frac{1}{4}$ flange plates 7 " $O$, 2 required.

4-Hastelloy B pipe 4"NPS, schedule 10, 4 "long.

5-Hastelloy B pipe I" NPS, schedule $40,2^{\prime \prime}$ long.

6-Monel adapter, $\frac{1 "}{4}$ NPS male $\times \frac{1}{4}$ O D tube, 5 required.

7 -Copper $\frac{1 "}{4}$ tubing cooling coils, brazed to fube wall.

8-Baffle plate, $3 \frac{1 "}{2}$ diameter $\times 0.045^{\prime \prime}$ thick.

9-Polyethylene gaskets.

10-Coupon specimen support $\frac{1^{\prime \prime}}{4}$ OD, Hastelloy B fube with Inor 8 wire hooks.

11-impingement specimen.

12-Off-gas exhaust.

13-Hastelloy $W$ tube, $\frac{1 "}{4} O D$ $\times 0.035^{\prime \prime}$ wall thickness.

FIGURE 3. DESIGN DETAILS OF HASTELLOY B CONTAINER 

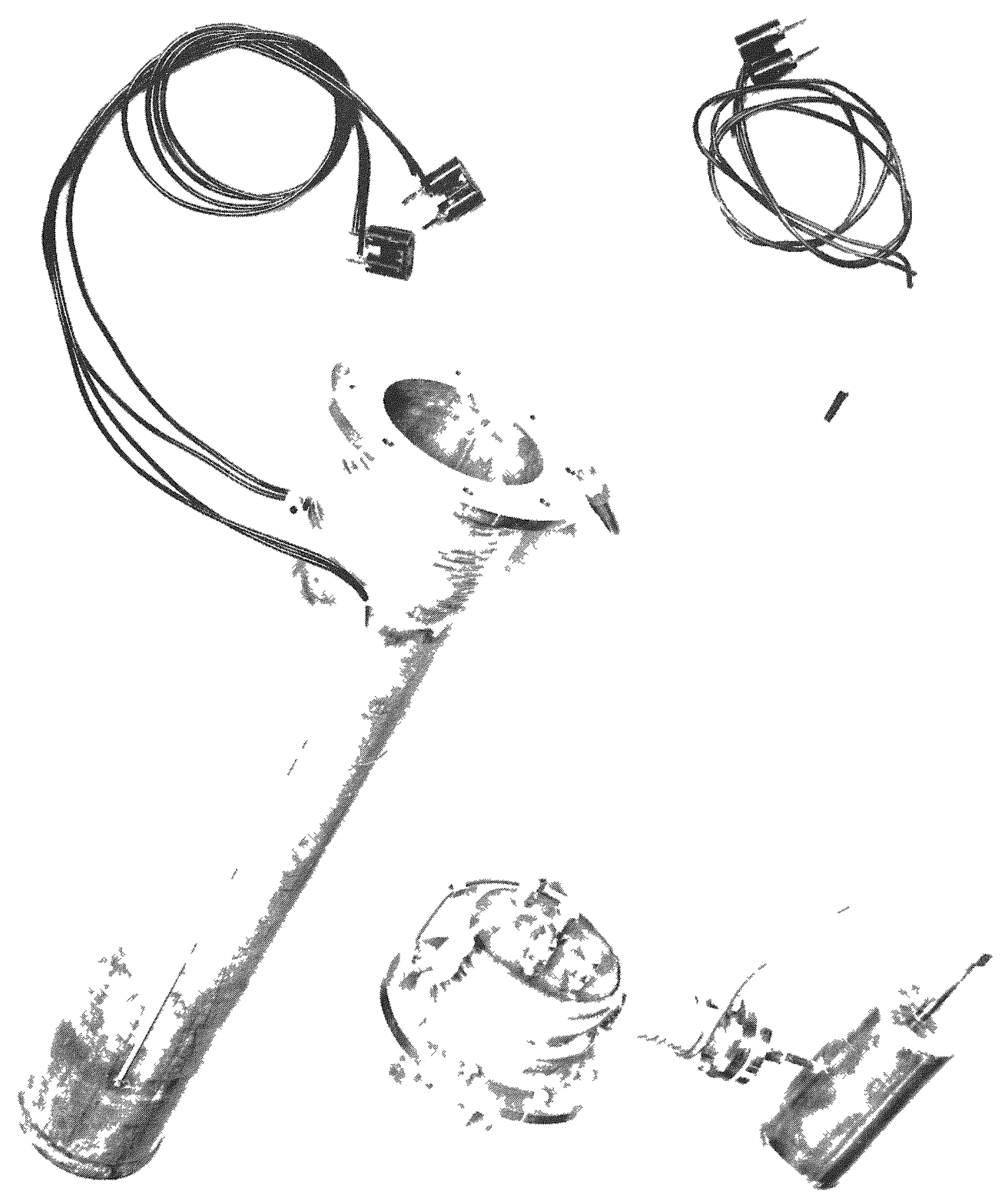

*

N48626

FIGURE 4. HASTELLOT B CONTAINER AND CLOSURE SHOWING GAS-IMPINGEMENT SPECIMEN 
plate was normally used at a lower position than shown in the photograph. It was usually placed about 4 in. above the salt level.

Figure 5 shows two assemblies in operating position in the electric furnaces. Figure 6 is a photograph of the complete arrangement from HF tank to flowmeter, purification furnace, corrosion assembly, bubble bottles, and KOH absorbers.

\section{Corrosion Results}

The initial studies were made in Inconel containers loaded at ORNL to a depth of about 7 in. with an equimolar mixture of $\mathrm{NaF}$ and $\mathrm{ZrF} 4$.

The salt was melted under an atmosphere of nitrogen and the thermocouple well and sparge tube holding the specimen were immersed. The HF flow was started and, after about $2 \mathrm{hr}$, the nitrogen flow was stopped. The procedure was reversed at the conclusion of the run.

Following exposure, the specimens were freed from adhering salt by soaking in boiling $2.5 \mathrm{w} / 0$ ammonium oxalate solution.

Several materials were evaluated in this series of experiments. Table $l$ lists the corrosion rates for these materials calculated from weight-loss measurements and from measurements of the amount of sound metal as revealed by metallography.

It can be seen that Incone1, "A" Nicke1, and Monel showed relatively high corrosion rates. Hastelloy $W$, INOR -1 , and INOR -8 were much more corrosion resistant.

Incone1

Metallographic sections of Inconel specimens showed that selective leaching occurred on the outer layers of the metal. The thickness of this layer was directly related to the length of time the specimen was exposed to HF in the fused salt. Figure 7 shows photomicrographs of sections from the tubes used for three of the experiments. As would be expected, the corrosion rates calculated from the sound metal shown on the metallographic specimen were much higher than those obtained from weight-loss mea surements (see Table 1).

In Run 11, the Inconel tube supporting the INOR-1 specimen was severed by corrosion after about $430 \mathrm{hr}$. The specimen and Inconel tube were covered at random with clumps of metallic crystals. Figure 8 shows a portion of the sparge tube and sections of the metal crystals adhering to it. The excessive selective attack on the Inconel can also be seen. Chemical analysis showed that the metal crystals were $93.5 \mathrm{w} / \mathrm{o}$ nickel and less than $0.1 \mathrm{w} / 0$ chromium. The remainder was probably composed of oxides of the metals present. An analysis of a portion of the Inconel tube showed selective leaching of the chromium. The analysis showed $77.7 \mathrm{w} / 0$ nickel and $7.6 \mathrm{w} / 0$ chromium.

The salt was drained from the melt container and the container was sawed into quarters. Figure 9 shows the appearance of one of the bottom pieces. It can be seen 


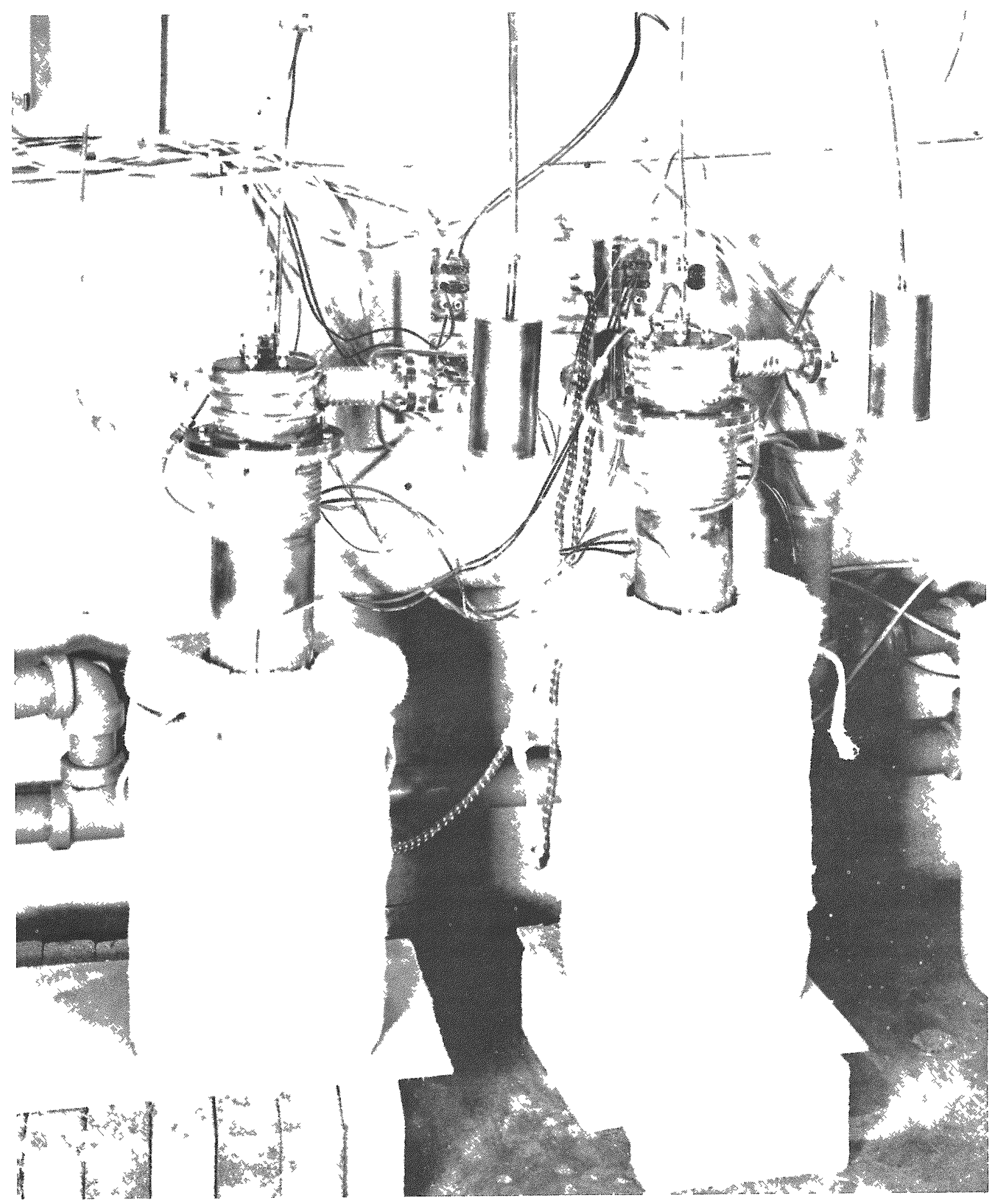

N48495

FIGURE 5. TWO ASSEMBLIES MOUNTED IN FURNACES 


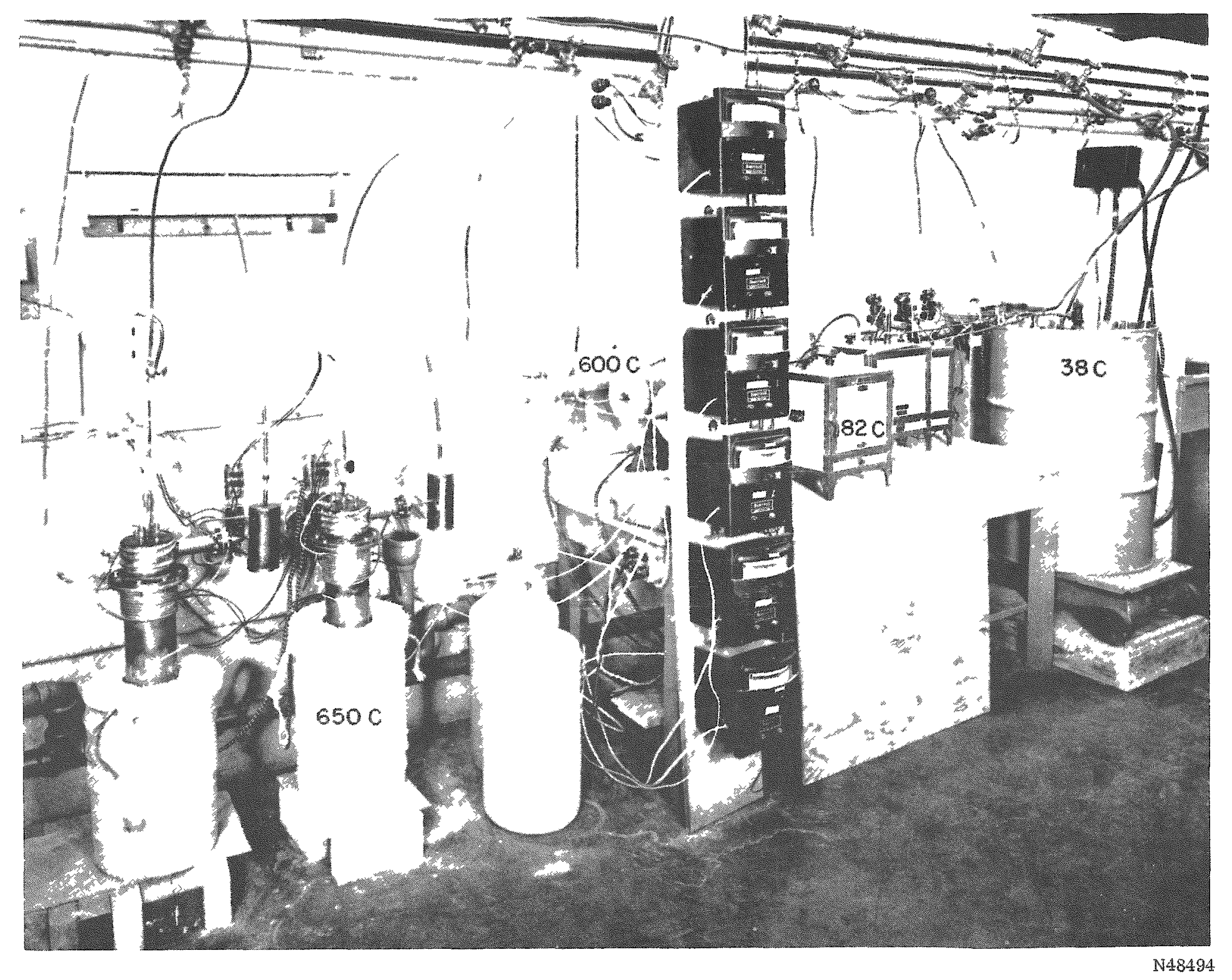

FIGURE 6. TWO COMPLETE ASSEMBLIES USED FOR HYDROF LUORINATION CORROSION STUDIES 
TABLE 1. RESULTS FROM FLUORIDE-VOLATILITY RUNS CONDUCTED IN INCONEL CONT AINERS

Equimolar $\mathrm{NaF}-\mathrm{ZrF}_{4}, 650 \mathrm{C}, 10 \mathrm{~g}$ per hr $\mathrm{HF}$

\begin{tabular}{|c|c|c|c|c|c|c|}
\hline \multirow[b]{3}{*}{ Run } & \multirow[b]{3}{*}{ Contanner } & \multirow{3}{*}{$\begin{array}{l}\text { Exposure } \\
\text { Time, hr }\end{array}$} & \multirow{3}{*}{$\begin{array}{l}\text { Specimen } \\
\text { Material }\end{array}$} & \multicolumn{2}{|c|}{$\begin{array}{l}\text { Corrosion Rate Determined by } \\
\text { Method Shown, mils per month }\end{array}$} & \multirow[b]{3}{*}{ Remarks } \\
\hline & & & & & tallogiaphic & \\
\hline & & & & Weight Loss & Section & \\
\hline 1 & $3-1$ & 36 & Inconel & 14 & 120 & Selective leaching \\
\hline 2 & $3-1$ & 96 & Inconel & 22 & 85 & Selecuve leaching \\
\hline 3 & $3-1$ & 2 & Inconel & 2.0 & 1400 & $\begin{array}{l}\text { Leaching proportional to } \\
\text { exposure time }\end{array}$ \\
\hline 4 & $6-1$ & 24 & Inconel & 39 & - & - \\
\hline 5 & $5-1$ & 250 & Hastelloy W & Gain $80 \mathrm{mg}$ & 3.6 & Some intergranular attack \\
\hline 6 & $2-1$ & 250 & INOR-8 & 0.09 & 1.0 & Some intergranular attack \\
\hline 7 & $4-1$ & 192 & "A" N1ckel & 8.9 & 6.8 & Intergranular attack \\
\hline 9 & $1-2$ & 8 & Copper & - & $-\infty$ & Immersion plate \\
\hline 10 & $4-1$ & 1000 & Monel & 5.2 & $4.6-9.2$ & Selecuve attack \\
\hline 11 & $1-2$ & 430 & INOR-1 & - & None & Crystal deposition \\
\hline 12 & $5-2$ & 64 & INOR-8 & - & 0.6 & Crystal deposition \\
\hline 13 & $5-2$ & 24 & INOR -8 & - & $-\infty$ & Few crystals \\
\hline 14 & $5-2$ & 186 & INOR -8 & 1.5 & 1.8 & No crystals \\
\hline
\end{tabular}



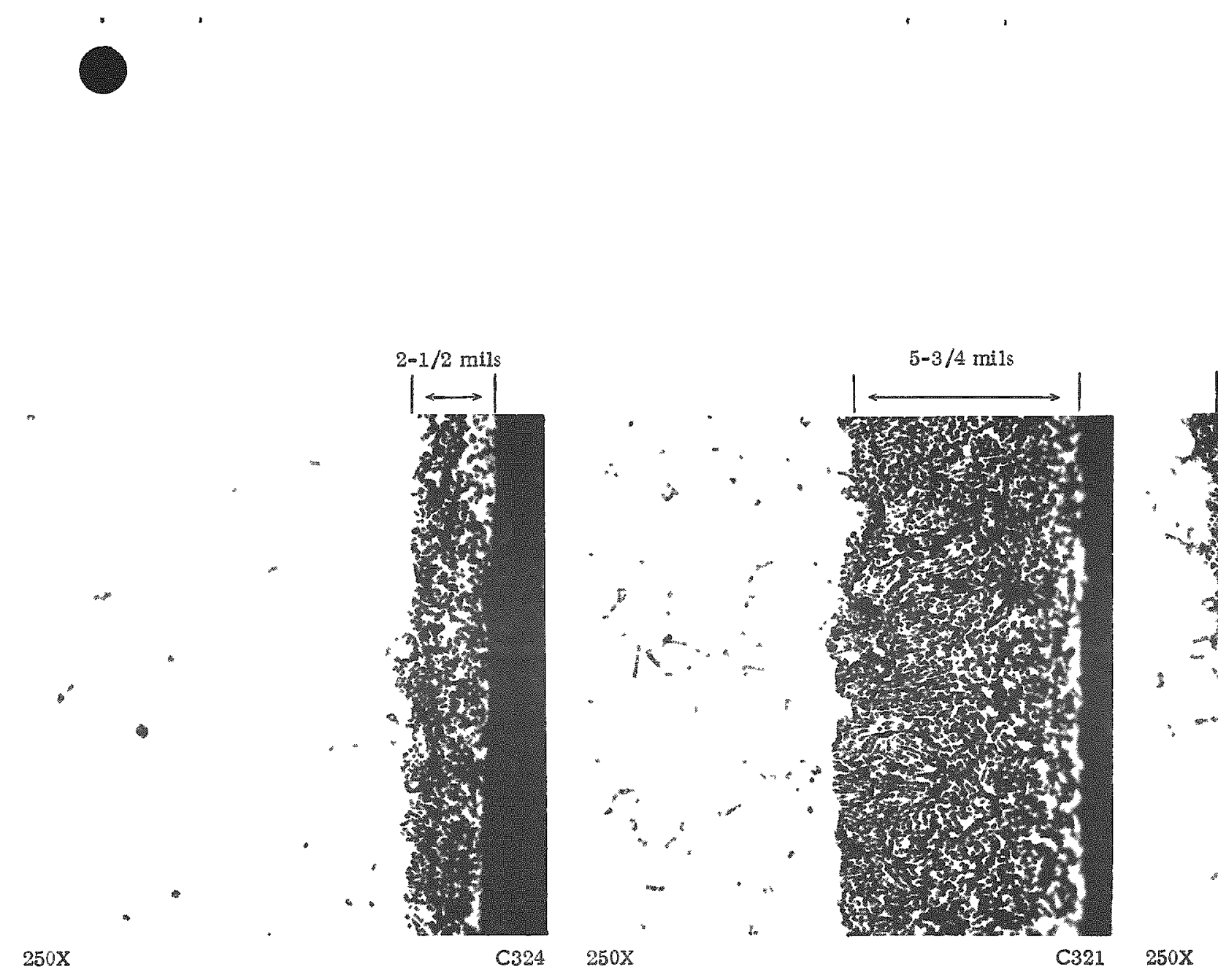

$9-1 / 2$ mils

Run 3,2 Hir

Run $1,36 \mathrm{Hr}$

FIGURE 7. PHOTOMICROGRAPHS SHOWING SECTIONS OF INCONEL SPECIMENS EXPOSED TO EQUIMOLAR NAF-ZIF 4 AT $650 \mathrm{C}$ WITH HF SPARGE 


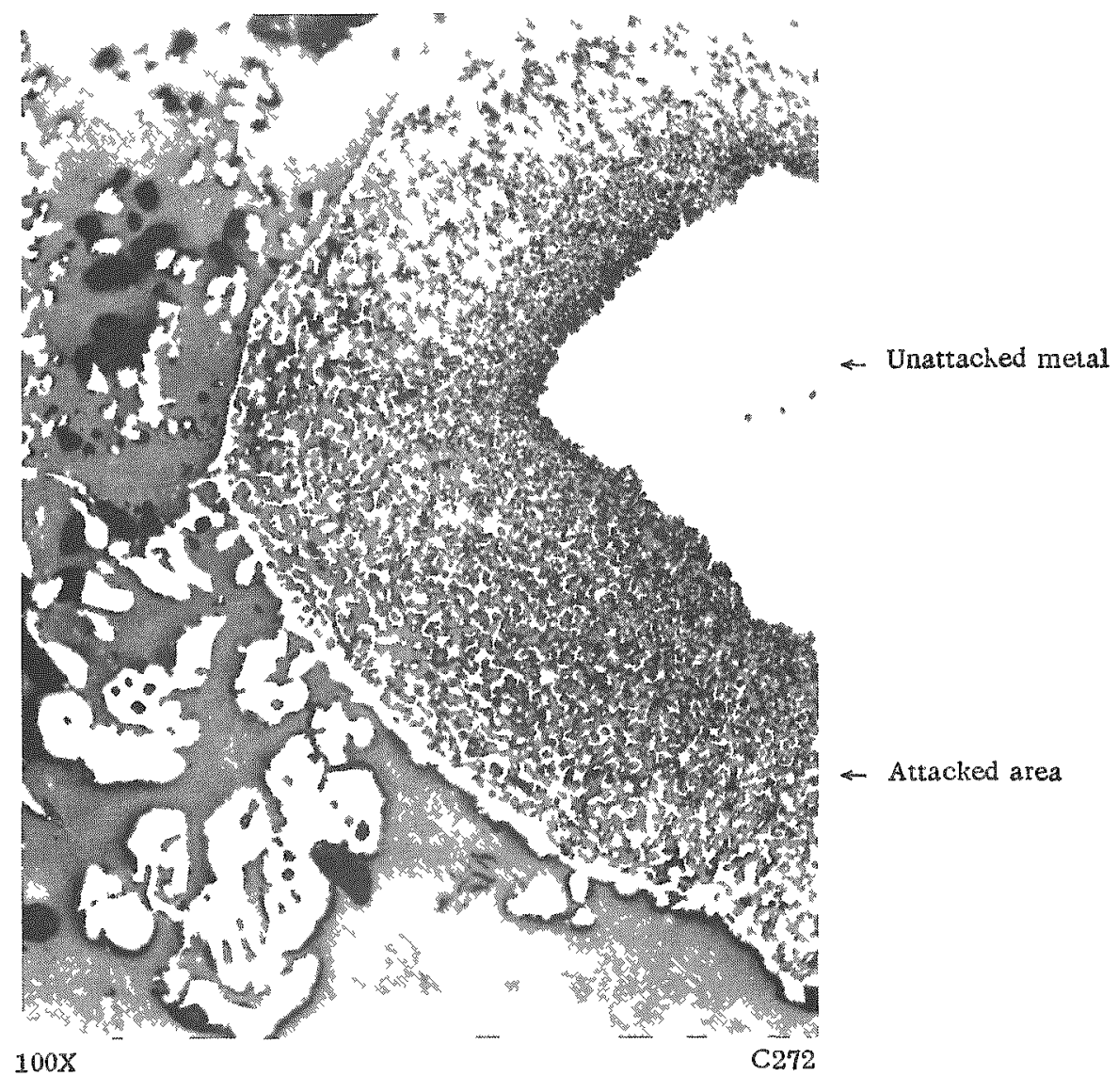

FIGURE 8. PHOLOMICROGRAPI OE SRLIION OI INCONEL SPARGE TUBE WHICH FAILED IN RUN 11 AND ADHERING METAL CRISTALS 


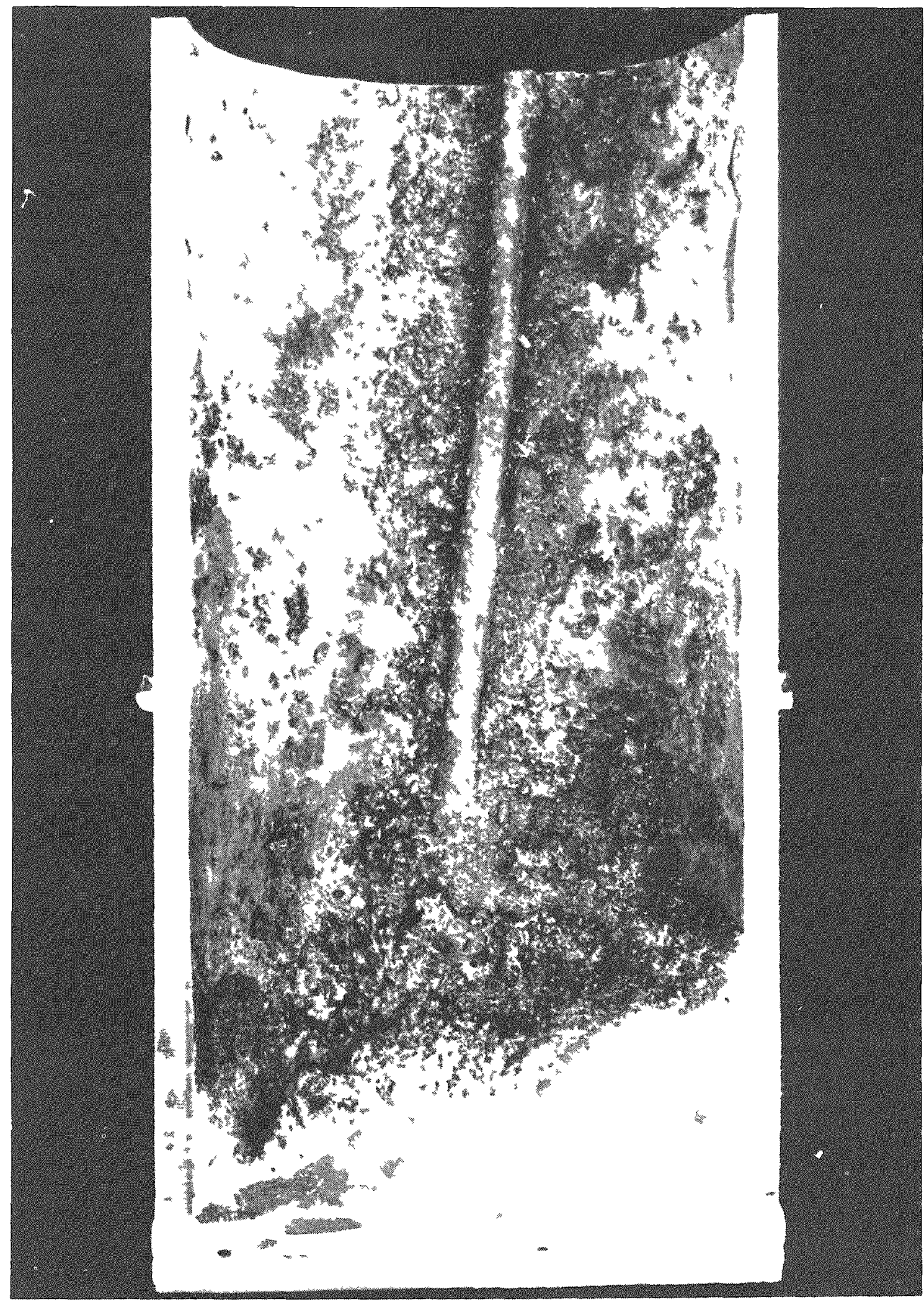

Approx. 1X

FIGURE 9. BOTTOM SECTION OF INCONEL CONTAINER AFTER RUN 11 
that a layer of metallic crystals was deposited around the inner surface. This layer reached a maximum thickness at about $7 \mathrm{in}$. from the bottom of the containe $r$ and at about $4.5 \mathrm{in}$. down from the liquid line. It should be noted that the salt level was higher than normal in this container. A considerable amount of sludge, probably metal crystals, remained interspersed with salt in the bottom section of the container.

"A" Nickel

Specimens of "A" Nickel (Run 7) showed a corrosion rate of almost 10 mils per month. The attack was intergranular. Figure 10 shows photomicrographs illustrating the attack which occurred at 192 and $1000 \mathrm{hr}$.

\section{Copper}

Results for copper were inconclusive because a metallic coating was deposited on the copper specimen during the exposure. The outer portion of this layer was soluble in nitric acid and gave a confirmatory test for nickel. No confirmation for chromium was obtained on a portion soluble in hot hydrochloric acid. As shown by the photomicrograph in Figure $1 \mathrm{la}$, this metallic layer was approximately 0.5 mil thick. It can be seen that grain growth occurred in the copper specimen during exposure.

Hastelloy W

In general, Hastelloy was quite resistant to attack. Figure 1 lb shows that some intergranular attack was found after an exposure of $250 \mathrm{hr}$. However, subsequent work in which $1 / 4$-in. Hastelloy $W$ tubes were used for thermocouple wells and sparge tubes indicated that it was much more resistant than Inconel or nickel.

Mone1

A Monel specimen held on a Monel sparge tube was exposed for $1000 \mathrm{hr}$. At some time during the exposure period, the sparge tube was severed by corrosion at the bent area. The penetration rate would be 25 mils per month if calculations were based on about $1000 \mathrm{hr}$. The specimen tube showed a penetration rate of 5.2 mils per month based on weight loss. Measurements made from the microsection show a penetration of 9.2 mils per month at the area swept by the gas and 4.6 mils per month at other areas. Figure $1 \mathrm{lc}$ includes a photomicrograph of a section of the Monel sparge tube after $1000 \mathrm{hr}$ of exposure. It can be seen that selective attack and roughening occurred at the surface during exposure.

\section{Silver}

Specimens of sheet silver were exposed in equipment made from Hastelloy B. Table A-2 in the Appendix shows the corrosion data obtained. Penetrations of about 7 to 9 mils per month were observed, based on weight-change values. Some difficulties were encountered because of mass transfer of silver. Crystals of the metal were deposited on other corrosion specimens and at various areas throughout the container. 


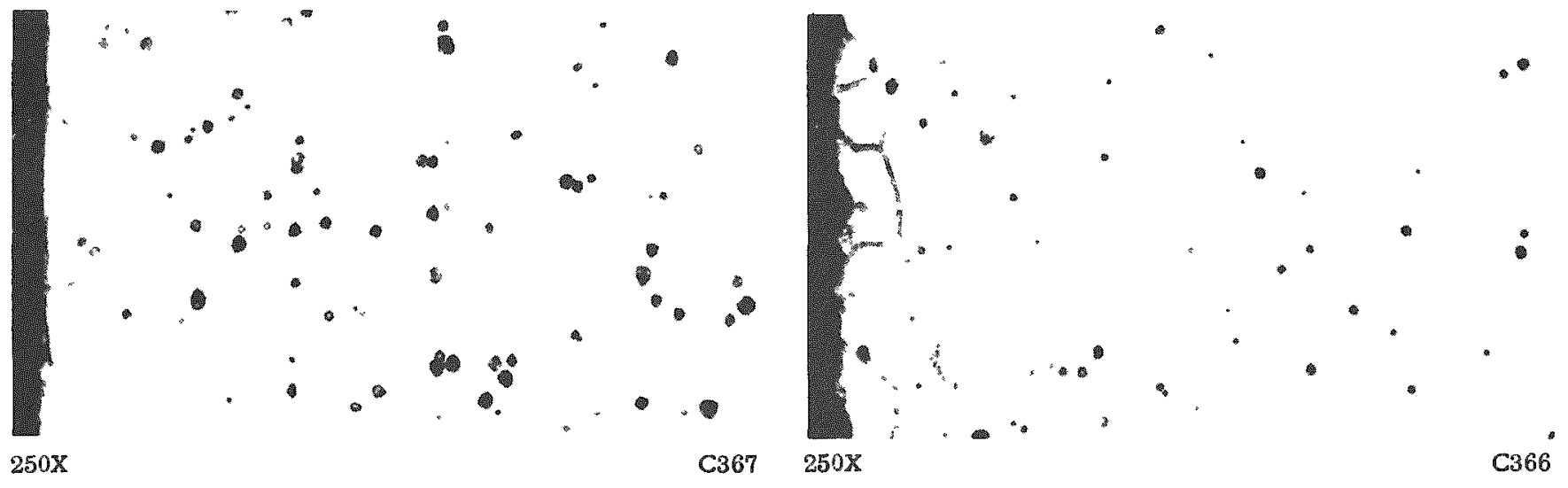

As Received

Nickel Impingement Specimen After $192 \mathrm{Hr}$

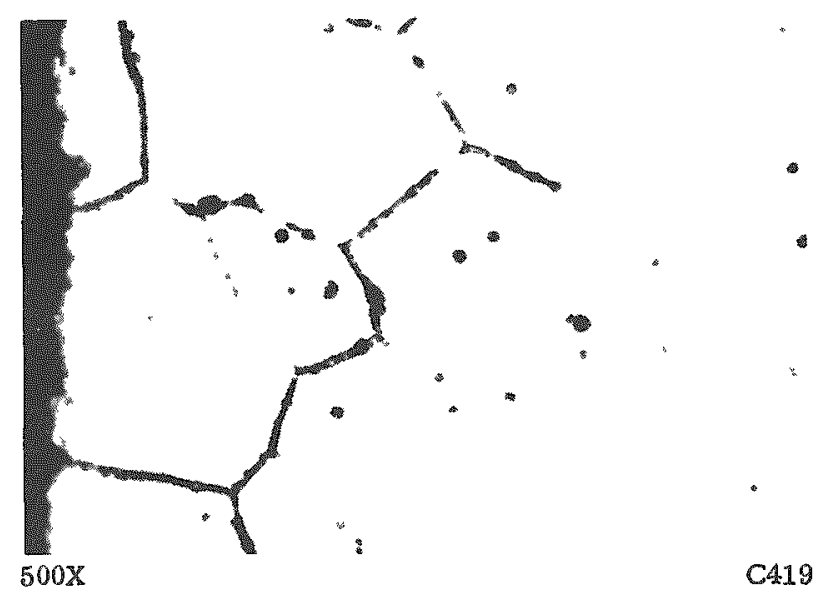

Nickel Thermocouple Tube Showing Intergranular Attack After $1000 \mathrm{Hr}$

FIGURE 10. PHOTOMICROGRAPHS SHOWING INT ERGRANULAR ATTACK OF NICKEL EXPOSED TO EQUIMOLAR NaF - ZIF AT $650 \mathrm{C}$ 


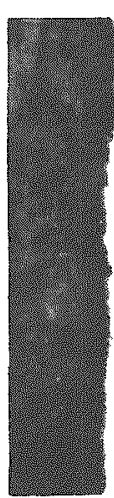

$250 \mathrm{X}$

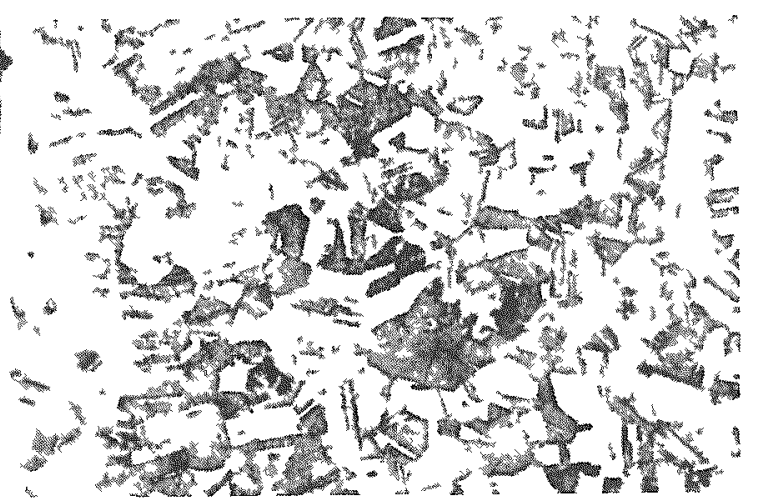

As Recerved

C368

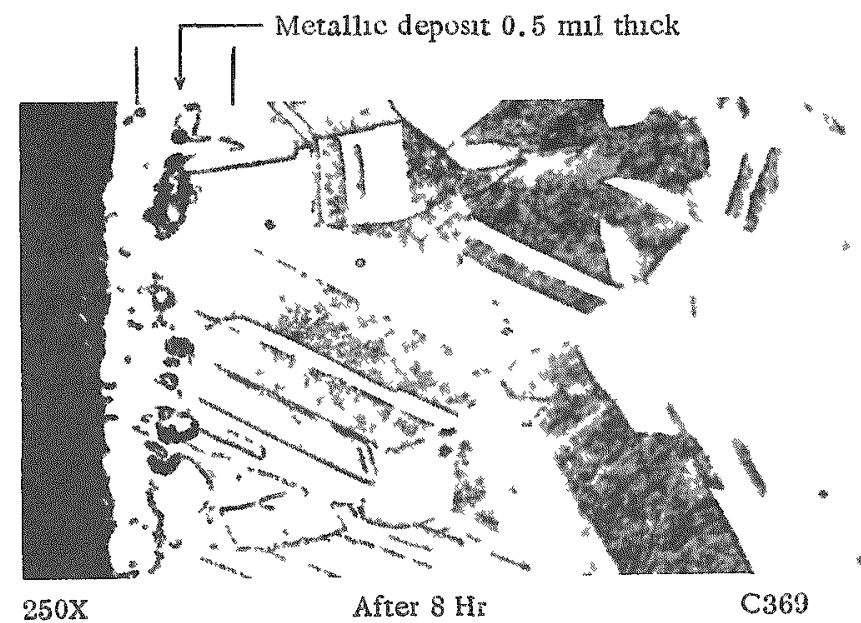

3. Deoxadized Copper

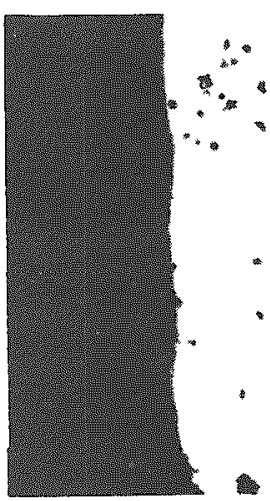

$250 \mathrm{x}$

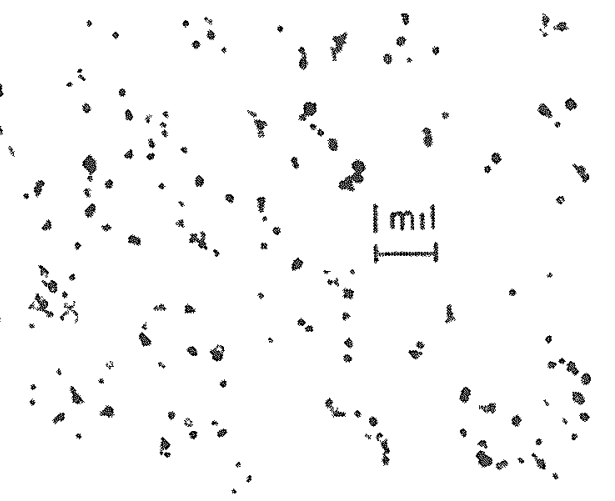

As Recelved

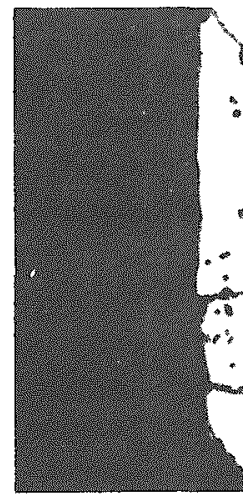

$250 \mathrm{X}$

b. Hastelloy $W$

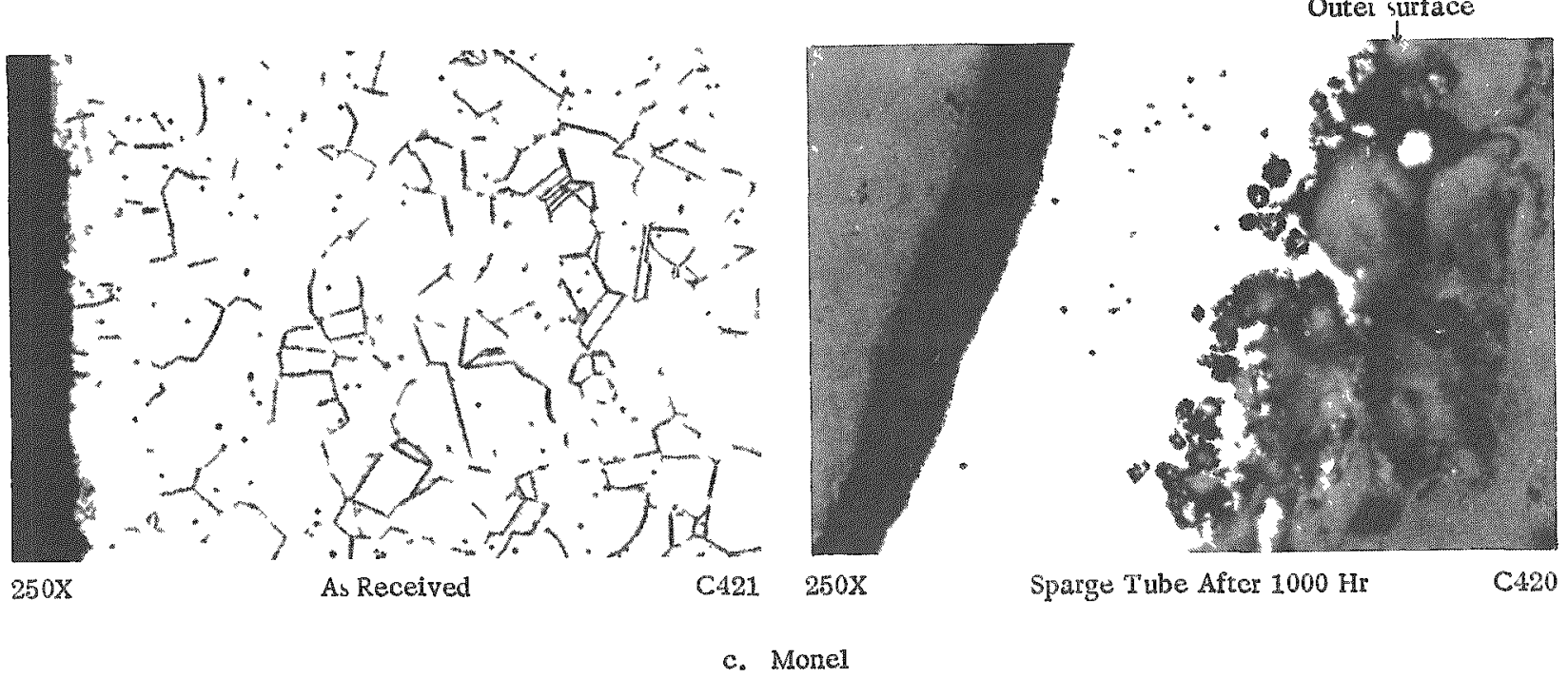

FIGURE 11. PHOTOMICROGRAPHS SHOWING SECTIONS OF SPECIMENS EXPOSED TO EQUTMOLAR $\mathrm{NaF}-\mathrm{ZTF}_{4}$ AT $650 \mathrm{C}$ WITH HIF SPARGE 
Hastelloy B

Containers made from Hastelloy $B$ have shown good service in a variety of salt compositions. Corrosion coupons of Hastelloy B were exposed during studies of INOR -8 which are described later. Table $A-2$ in the Appendix gives the penetration results for the Hastelloy pieces. It can be seen that its resistance is quite good in most cases. If it were not for its age-hardening characteristics and poor resistance to oxidation, it would be a top contender as a container material.

\section{INOR Alloys}

Since the initial studies showed that INOR -1 and INOR -8 were quite resistant, the work done in the improved containers made from Hastelloy B was confined largely to these materials. The containers were fitted with an easily dismountable head so that multiple corrosion specimens could readily be used. Most runs were made using tubular specimens mounted on the bottom of the sparre tube as was described earlier. In many cases, a tube of INOR-1 was also placed above the standard INOR-8 tube. In addition, coupons, approximately $1 / 2$ by $3 \mathrm{in.}$, of each of the above alloys were suspended at vapor, interface, and liquid positions. These coupons were fastened with INOR -8 wire to a 1/4-in. Hastelloy $W$ tube extending down from the closure. On occasion, tubes of INOR-8 or INOR-1 were suspended at the interface. A coupon of Hastelloy $B$ was included in many experiments so that an estimate of container life could be obtained.

Studies were made relating corrosion to the following variables:

(1) Salt composition

(2) Temperature

(3) Effects of atmosphere
(a) Flow rate of $\mathrm{HF}$
(b) Addition of hydrogen
(c) Addition of oxygen.

Table A-1 in the Appendix gives the details of the operating conditions used for these experiments.

Fluoride salts representing compositions for beginning, middle, and final stages during dissolution were studied. Two general groups were represented: the NaF$\mathrm{ZrF}_{4}$ and the NaF-LiF types. In the NaF-ZrF 4 type, the compositions in mole per cent were:

$$
\begin{array}{ll}
\text { Beginning } & 62 \mathrm{NaF}-38 \mathrm{ZrF}_{4} \\
\text { Middle } & 50 \mathrm{NaF}-50 \mathrm{ZrF}_{4} \\
\text { Final } & 4.3 .5 \mathrm{NaF}-56.4 \mathrm{ZrF}_{4}-0.11 \mathrm{UF}_{4} .
\end{array}
$$


In the NaF-LiF type the compositions studied were:

$$
\begin{array}{ll}
\text { Beginning } & 43 \mathrm{NaF}-57 \mathrm{LiF} \\
\text { Final } & 19.3 \mathrm{NaF}-25.6 \mathrm{LiF}-54.9 \mathrm{ZrF}_{4}-0.21 \mathrm{UF}_{4}
\end{array}
$$

The corrosion was evaluated by weight changes, by dimensional changes, and by metallographic examinations. The results, expressed as penetration in mils per month, are summarized in Iable A-1 in the Appendix. The table also includes details of the operating conditions used for each run.

It was found that invariably the corrosion was greatest at the vapor-liquid interface areas. Figure 12 shows the appearance of coupons and tubes after $263 \mathrm{hr}$ under one of the more severe conditions (Run 20). The Hastelloy B melt container used in this run showed severe local attack. The bottom half of this container was sawed off and it was then split lengthwise. Figure 13 shows an enlargement of the section near the vapor-liquid interface area. Severe localized penetration is visible on the polished edges of the container wall.

While the runs were in progress, potential measurements were made between the Hastelloy $B$ melt containers and the insulated Hastelloy $W$ tubes which support the specimens. The potential difference in the container with the INOR -8 specimen varied from 0.2 to $0.4 \mathrm{mv}$. These values measured with the Hastelloy $B$ melt containers are only about 5 per cent of those previously obtained during similar measurements with an INOR-8 specimen in an Inconel container. It was under this latter condition that metallic crystals were found on the INOR -8 specimen. The implications are that the crystal deposition which occurred was not entirely a result of mass transfer but may have arisen from galvanic effects between the specimen and the container.

A 7 -in. INOR-8 coupon specimen was suspended in the container during Run 24 so that it encompassed the entire range ordinarily covered by the three coupon-type specimens. Figure 14 shows a profile of the corrosion rates at various points along this specimen as calculated from thickness losses. The heavy attack on the submerged portion and the necking down at the interface are apparent. The bulge in the vapor section of the curve probably is indicative of the splash zone.

The Hastelloy $W$ thermocouple well, sparge tube, and specimen-support tubes all showed severe attack. The thickness of the sparge tube was reduced to half of its original value at one point and the support tubes were severed at the liquid line.

Information on the corrosion behavior of INOR -8 in both sodium-zirconium and sodium-lithium systems is presented by bar graphs in Figure 15. Necking down of the specimens at the liquid line has been indicated by suitably tapering the bars. The rates indicated by solid bars are those computed from over-all weight losses. Higher rates, as determined from measurements by micrometer or by metallography, are indicated by the additional appropriate hatching of the bars.

Table A-2 in the Appendix gives detailed corrosion results for all specimens evaluated in this program. 


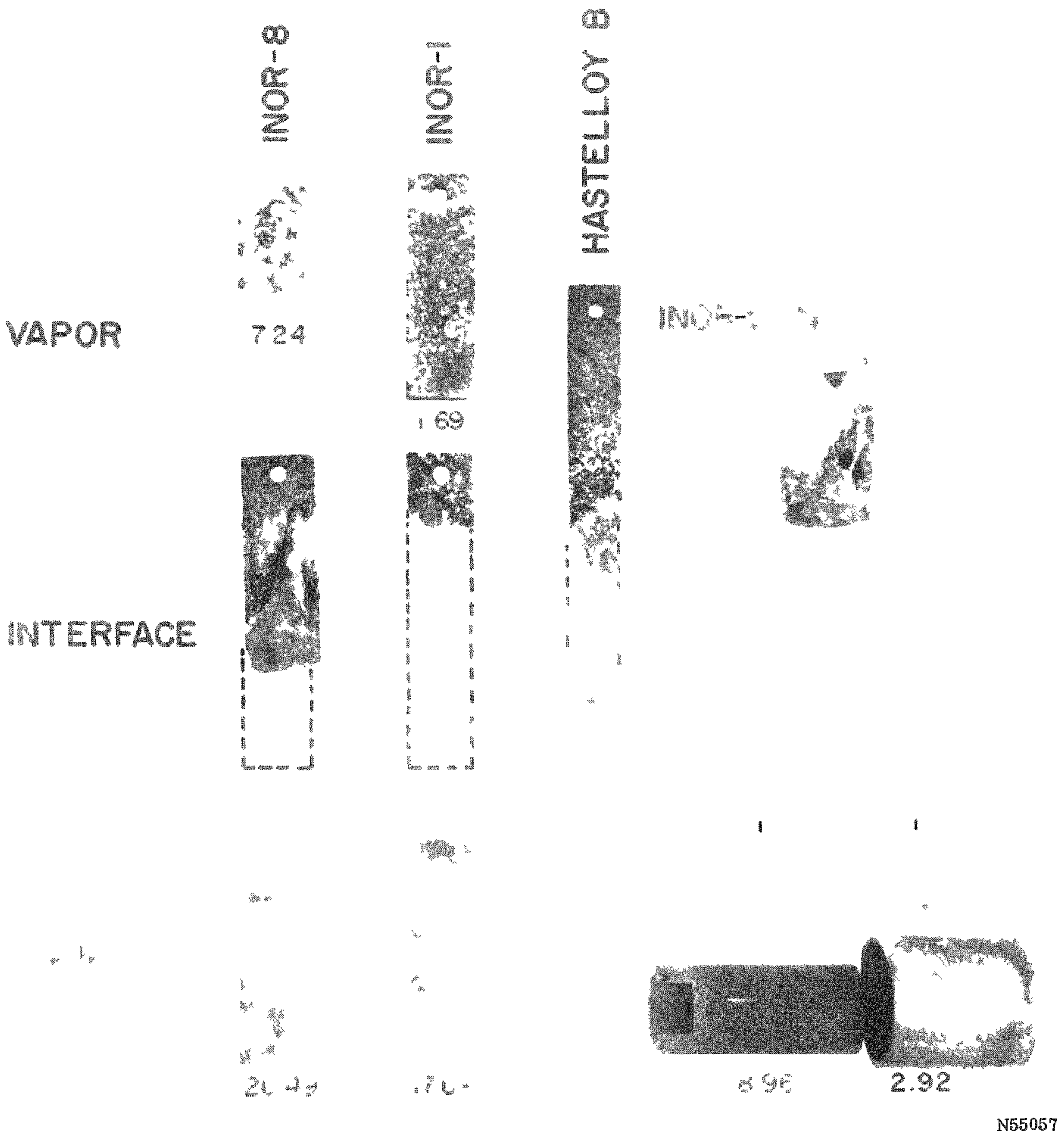

FIGURE 12. MATERIALS EXPOSED TO 43 MOLE PER CENT NaF-57 MOLE PER CENT LIF SALT AND $10 \mathrm{G} \mathrm{HF}$ PER HR FOR 263 HR AT $700 \mathrm{C}$

Corrosion rate is given in mils per month. Data were obtained in Run 20. 


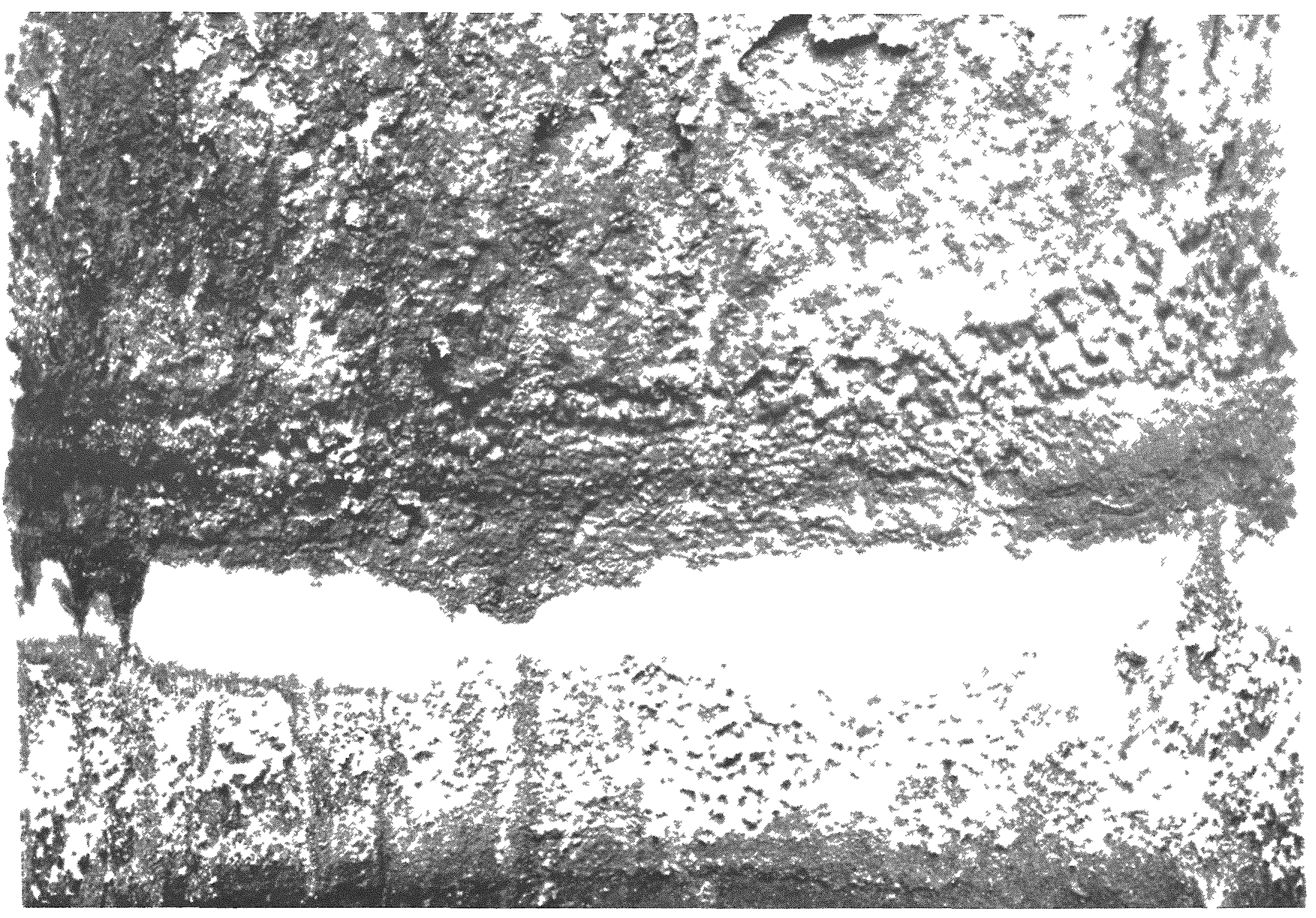

FIGURE 13. ऽECTION OF HASTELLOY B CONTAINER AFTER RUN 20

The area shown is at the liquid-vapor interface line Notice the penetration into the contaner wall. 


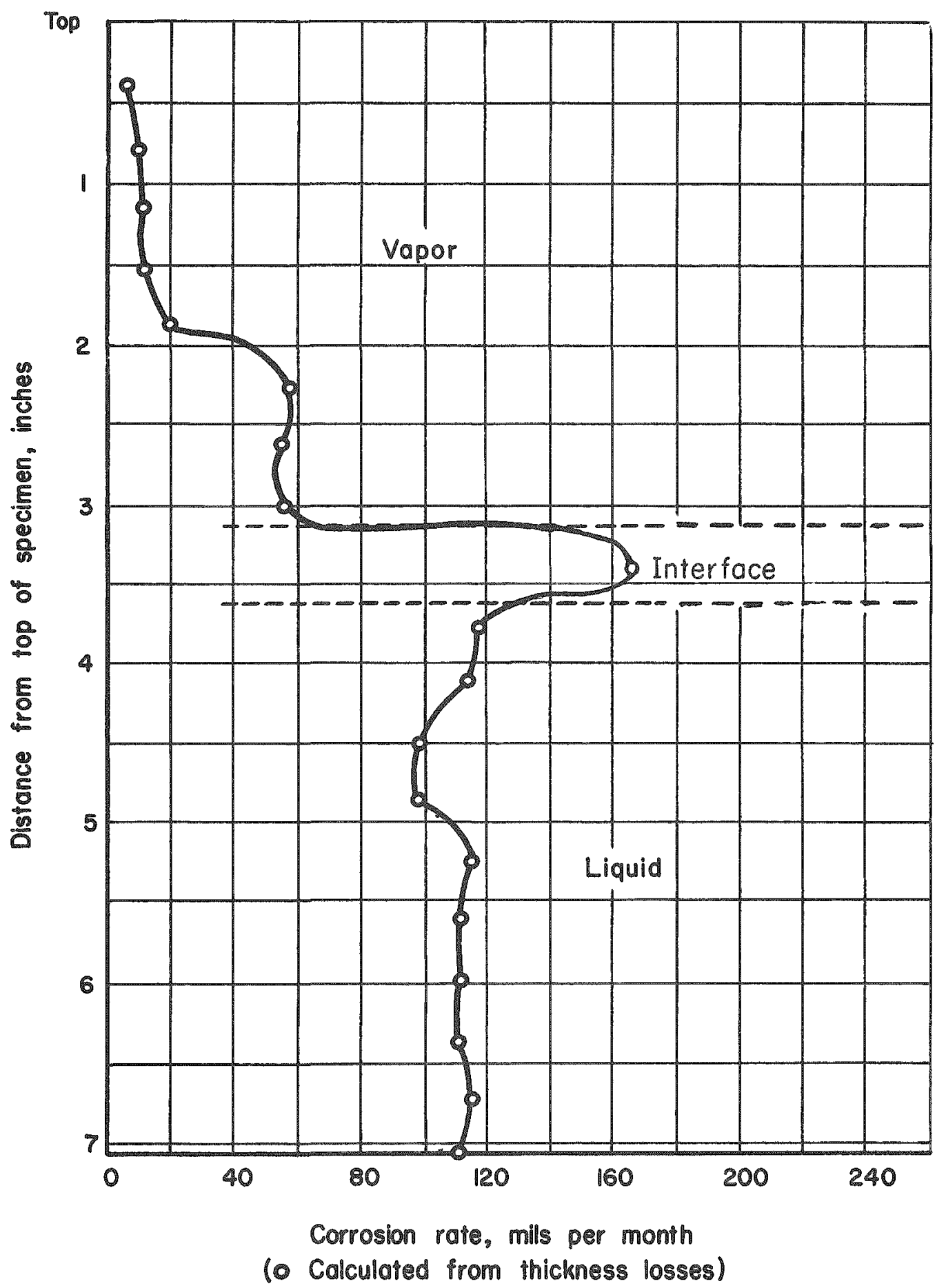

FIGURE 14. PROFILE OR CORROSION OF INOR-8 SPECIMEN EXPOSED FOR 93 HR AT 700 C TO 43 MOLE PER CENT NaF-57 MOLE PER CENT LIF SALT WITH $10 \mathrm{G} / \mathrm{HR}$ HF

Values computed from micrometer measurements of loss in thickness. Data are from Run 24. 

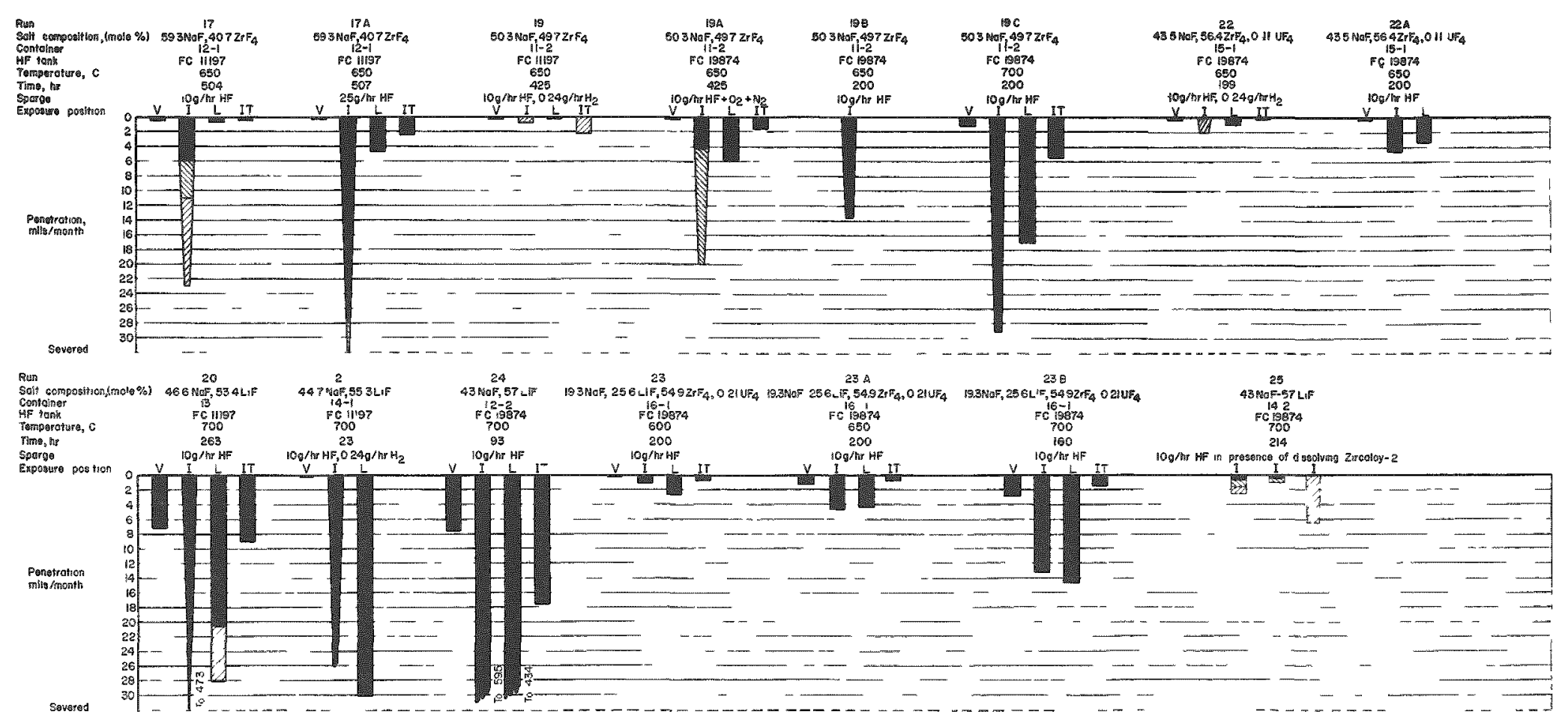

Weight loss, mits per month

Micrometer messurement, muls per month

CMatalicgroghis mecsuremens, mis per month

$\left.\begin{array}{ll}\begin{array}{l}V \\ I\end{array} & \text { Vapor } \\ 2 & \text { Linterface } \\ \text { IT } & \text { impingements }\end{array}\right\}$ tabe

Toper of bor indicates necking of specimen
ot interface ond liguilo
portions

FIGURE 15. SUMMARY OF CORROSION RESULTS FOR INOR-8 IN FLUORIDE-VOLATILITY PROCESS SYSTEMS 
The corrosive attack on INOR -8 material was sometimes general in nature and sometimes intergranular. Figure 16 shows photomicrographs illustrating the progressive roughening and surface attack on specimens exposed in the liquid phase caused by increased salt temperatures.

Typical intergranular attack for INOR -8 and INOR-1 material is shown in Figure 17 for interface specimens. It can be seen that the penetration is somewhat greater for the INOR -8 material in this particular experiment.

The data indicate that the sodium-lithium systems are much more corrosive to the alloys under study than the sodium-zirconium systems. An elevation in temperature increases the corrosion significantly, as does an increase in the HF flow rate. The presence of hydrogen will mitigate the corrosiveness of the sodium-zirconium salts but its effect on the sodium-lithium systems has not been fully determined.

The corrosiveness of a given salt seems to be directly related to its alkali fluoride content. In the case of the sodium-zirconium salts, three mixtures which might represent beginning, middle, and final stages of the hydrofluorination have been studied. Generally, corrosion decreases with increasing zirconium content. Possibly formation of complexes accounts, in part, for this. The exact composition of complexes at various stages in the fluoride system is not known, nor is their degree of dissociation established, but, for argument's sake, consider the complex $\mathrm{NaZrF}_{5}$ known to exist to some extent. For example, in the 60 mole per cent NaF-40 mole per cent $\mathrm{ZrF}_{4}$ salt the re would be a deficit of zirconium for forming the $\mathrm{NaZrF}_{5} \mathrm{com}-$ plex equal to 1 mole of NaF per 2 moles of $\mathrm{NaZrF}_{5}$. At the other end of the scale, i. e., 43 mole per cent $\mathrm{NaF}^{-57}$ mole per cent $\mathrm{ZrF}_{4}$, all of the NaF could be complexed, leaving an excess of 1 mole of $\mathrm{Z}_{\mathrm{r}} \mathrm{F}$ per 3 moles of $\mathrm{NaZrF}$. Of course in the equimolar salt, complete complexing with no dissociation would result in no excess of either component. The 60 mole per cent $N a F-40$ mole per cent $\mathrm{ZrF}_{4}$ salt was used for Run 17, the equimolar for Run $19 B$, and the 43 mole per cent $N a F-57$ mole per cent ZrF4 for Run 22A. Comparing the corrosion rates for these runs indicates that the hypothesis above may have some merit.

The severe localized attack which occurs at the liquid line has been noted on several occasions. In contrast to this, the impingement specimens on the sparge tube which certainly have an interface, albeit a constantly moving one, do not always show significant localized attack. Many times, coupons and their support tubes were severed at the liquid line, while little attack occurred on the sparge tube which is more directly in line with the rising HF bubbles. A possible explanation for these observations lies in gradients of temperature and composition at the liquid-vapor

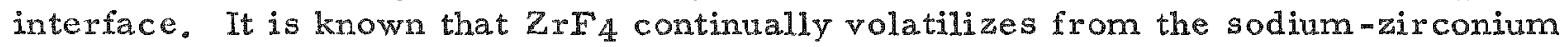
melts. This would leave the immediate surface with a preponderance of alkali fluoride. Near the sparge tube, the agitation by the bubbling HF tends to decrease this composition gradient and, consequently, corrosion is not so severe. At the interfaces created on the impingement specimens, the opportunity for rapid replenishment of the volatilized $\mathrm{ZrF}_{4}$ exists; consequently, the same conditions do not occur here as at the liquid line. The actual localized attack at the liquid line is undoubtedly electrochemi cal, arising from differences in potential between the portion of the specimen submerged and the portion at the liquid line. These differences could easily be influenced by virtue of the difference in the relative solubility of HF in the liquid phase and in the 


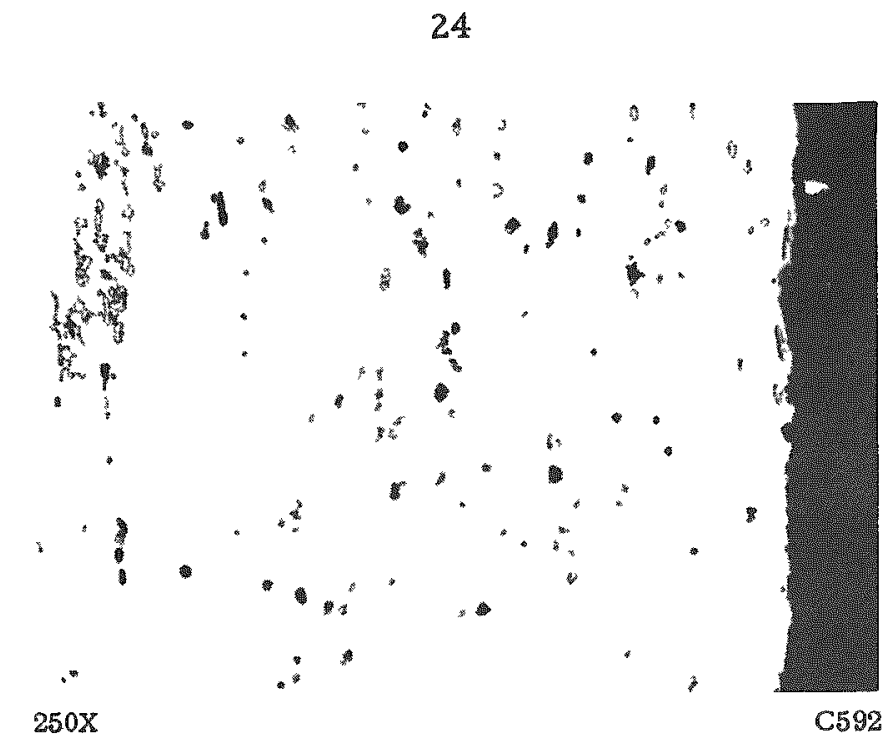

a. After $200 \mathrm{Hr}$ at $600 \mathrm{C}(\operatorname{Run} 23)$

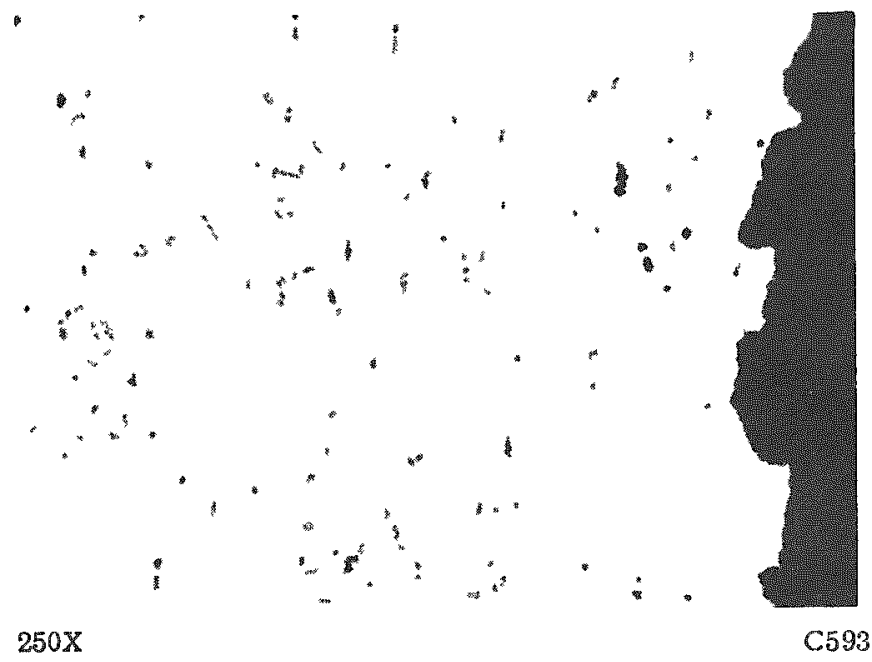

b. After 200 Hr at $650 \mathrm{C}(\mathrm{Run} 23 \mathrm{~A})$

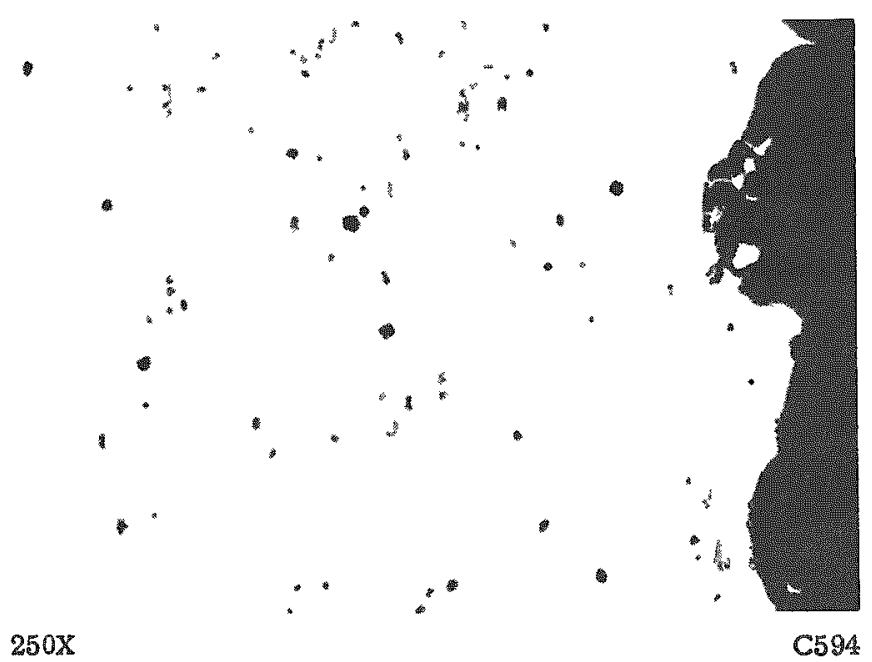

c. After $160 \mathrm{Hr}$ at $700 \mathrm{C}$ (Run 23B)

FIGURE 16. PHOTOMICROGRAPHS SHOWING THE ATTACK ON INOR-8 AT VARIOUS TEMIPERATURES IN NaF-LAF SALTS 


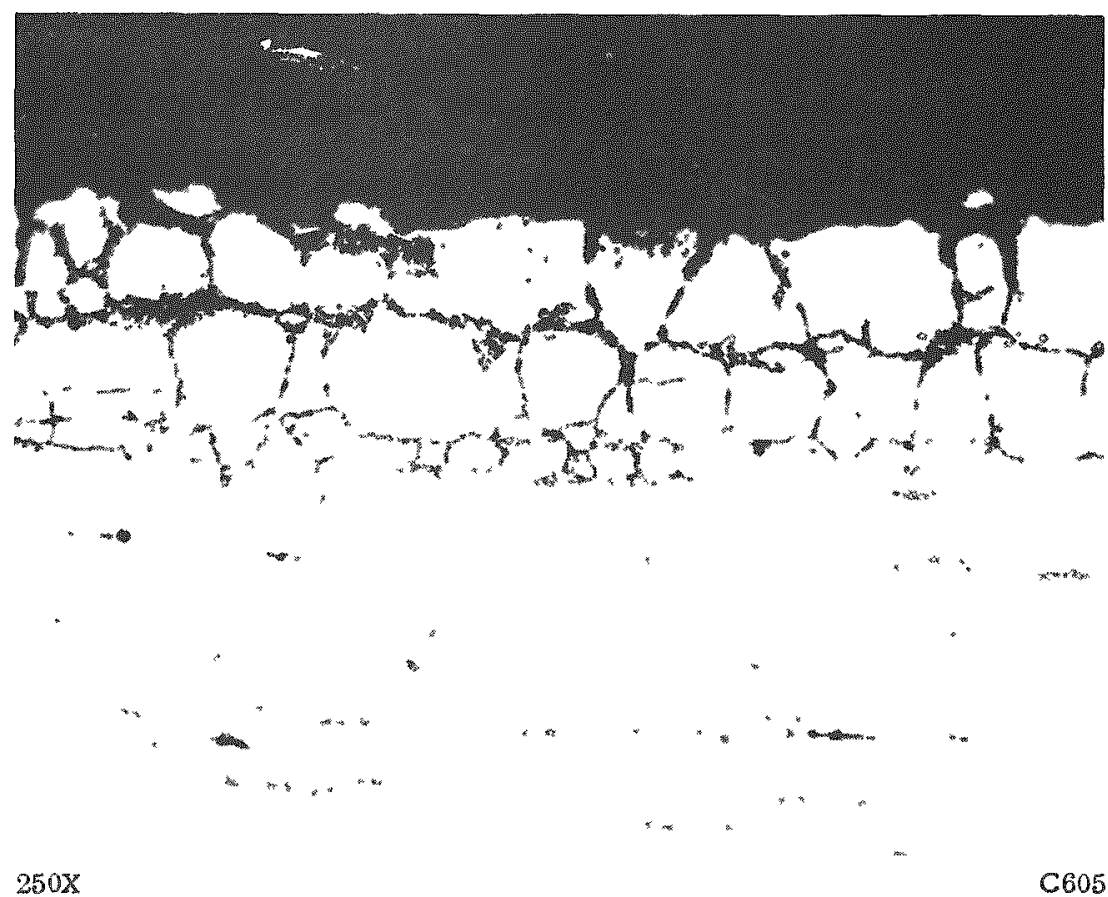

INOR-8

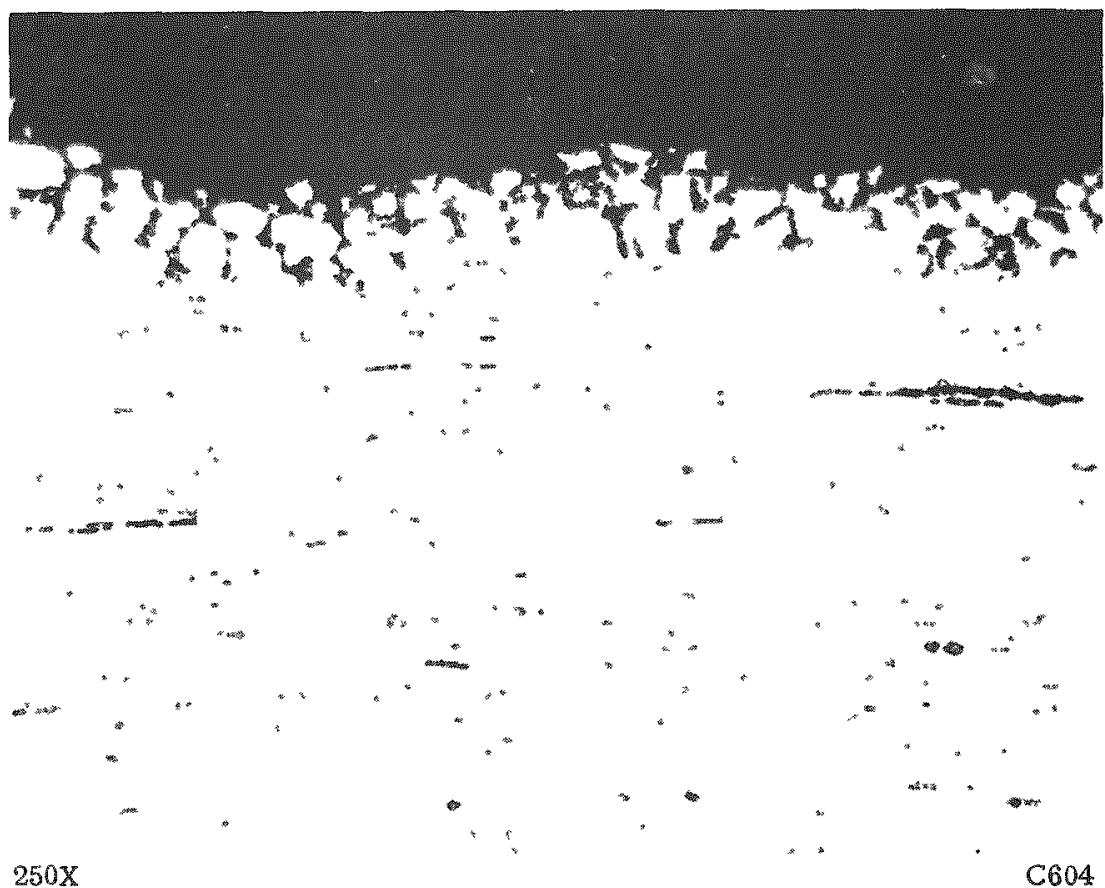

INOR-1

FIGURE 17. PHOTOMICROGRAPHS SHOWING INT ERGRANULAR ATTACK ON SPECIMENS EXPOSED AT THE INTERFACE POSITION TO 43 MOLE PER CENT NaF-57 MOLE PER CENT LIF SALT AT 700 C FOR 93 HR (RUN 24) 
partial pressure of $H F$ in the vapor. The fact that increasing the flow of HF causes increased corrosion seems to support this mechanism. However, if one considers the lower rates on the impingement specimens with increasing flow of HF, the argument for concentration gradients at the liquid-vapor interface as a cause of the attack seems to be more reasonable.

In order to obtain a better understanding of the corrosion mechanism, an experiment was made in which dissolving Zircaloy-2 was present at all times. The objective of the work was to determine whether cathodic protection is furnished to the container (Hastelloy B) and the INOR -8 coupons by dissolving Zircaloy-2. In addition, such effects as a constant evolution of hydrogen, consumption of a portion of the entering HF stream, a gradual increase in the zirconium content of the salt, and a moving liquidvapor interface could be examined. Work by G. I. Cathers and associates at ORNL had indicated that less severe corrosion could be anticipated under these conditions.

Figure 18 shows the container head and specimen-mounting arrangement used. The central pipe of 1 -in. nickel was used for charging Zircaloy-2 slugs to the molten salt. A vapor-lock section located above the gate valve shown in the photograph permitted loading charges of Zircaloy -2 as desired. The vapor lock was flushed with argon continuously. Seven slugs, $0.6 \mathrm{in}$, in diameter and $1.8 \mathrm{in,} \mathrm{long,} \mathrm{weighing}$ approximately $52 \mathrm{~g}$ each, were dropped simultaneously into the salt at 30 to $40-\mathrm{hr}$ intervals.

Several specimens of INOR-8 were evaluated. One coupon about $5 / 8$ in. wide and $7 \mathrm{in.}$ long was attached to the thermocouple well (INOR-8, 1/4-in. tubing) with an INOR -8 wire. The photograph shows that this well was insulated from the container head by a Teflon sleeve. The thermocouple well and coupon were raised twice a day as the salt level in the container rose. Thus, the interface position was maintained at approximately the same area on the specimen. Another coupon about 11 in. long was wired to the 1/4-in. INOR-8 sparge tube and was left permanently in position during test. A double specimen was welded to the end of a third 1/4-in. INOR -8 tube. This tube was raised periodically to maintain a fairly constant interface position on the specimens. Only the thermocouple well and its attached specimen were electrically insulated from the container.

A 3 by 3 -in. lap-welded coupon of INOR-8 containing a crevice was placed on the bottom of the container to obtain additional corrosion results.

The rate of dissolution was followed by three measurements. The volume of hydrogen was measured continuously with a wet-test meter after the HF had been removed. The rise in liquid level in the container was followed by dip-stick-contact measurements using the movable thermocouple well. A differential-pressure gage connected across the gas-inlet and -exit sides of the container also indicated the rise in liquid level. Figure 19 illustrates the type of data accumulated from these three measurements. The curve for theoretical hydrogen evolution was calculated on the basis of 100 per cent efficiency of dis solution at a flow rate of $9.5 \mathrm{~g} \mathrm{HF}$ per hr. It may be seen that the amount of hydrogen evolved varied directly with the HF flow. The actual volume of hydrogen measured was 75 per cent of the theoretical, based on the total $\mathrm{HF}$ introduced.

Nine per cent of the $1980 \mathrm{~g}$ of Zircaloy -2 added to the salt remained undissolved on the bottom of the container at the end of the run. The final salt level was about 4 in. higher than the initial level. 


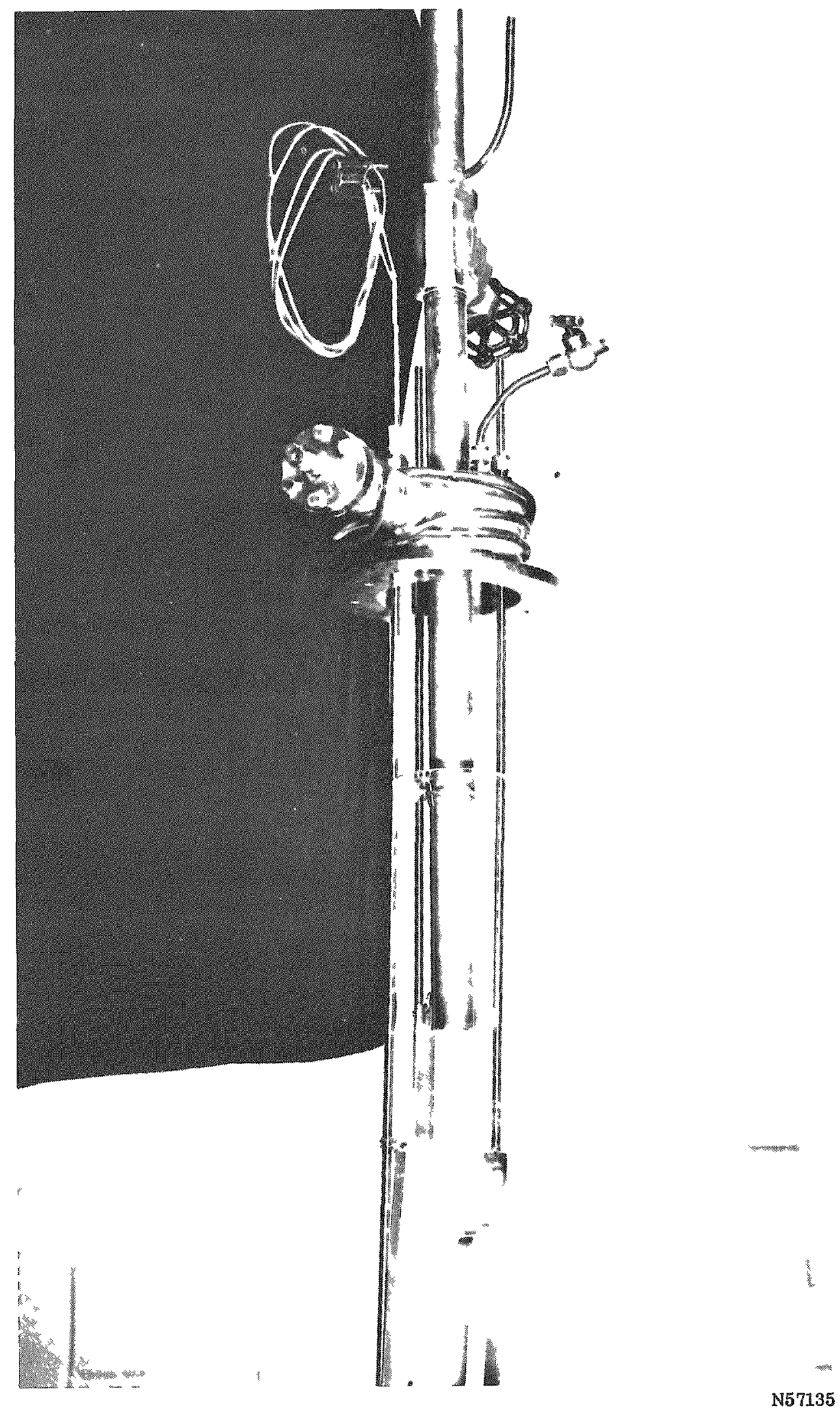

FIGURE 18. SPECIMENS AND CHARGE TUBE FOR CORROSION STUDIES IN THE PRESENCE OF DISSOLVING ZIRCALOY-2 


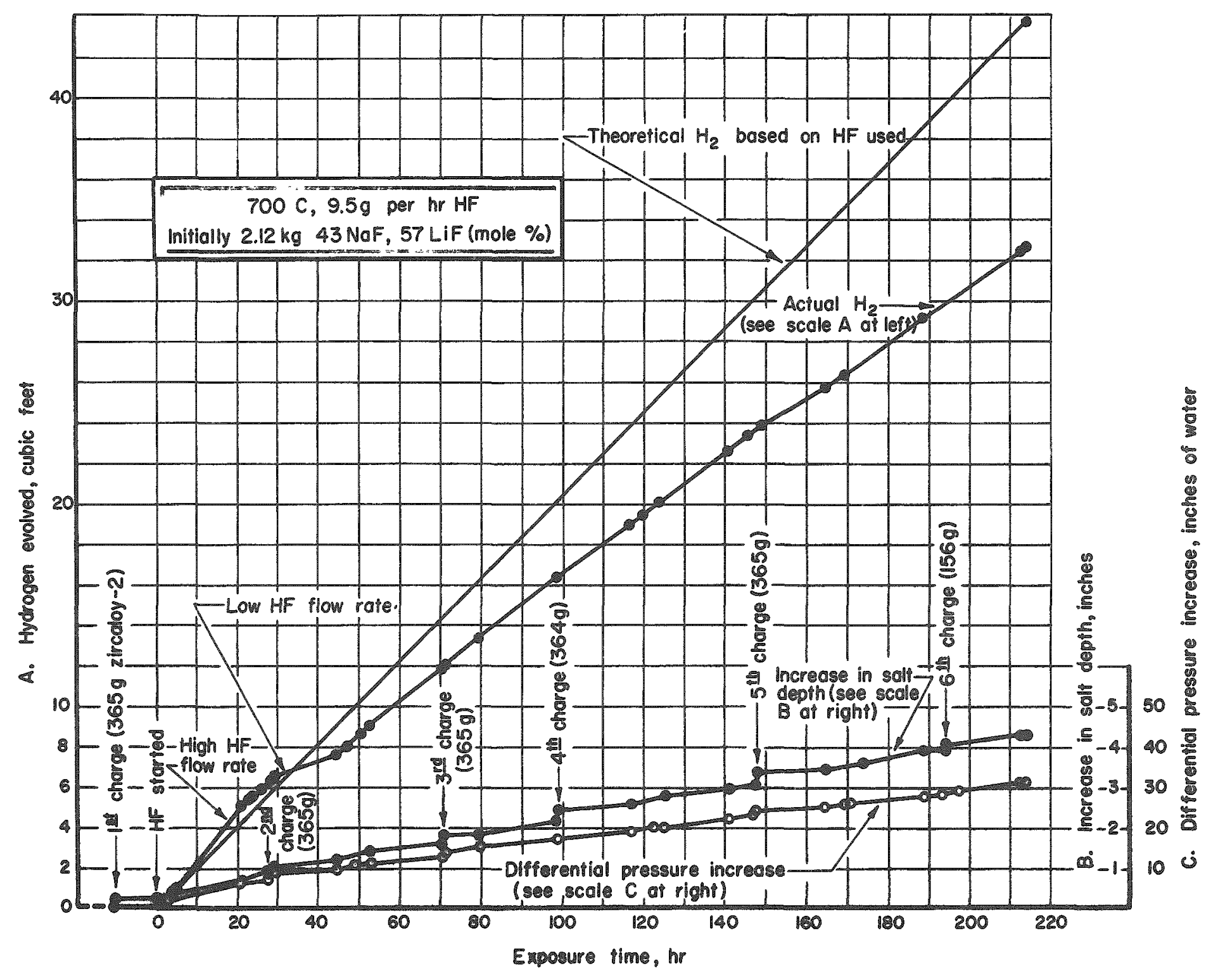

FIGURE 19. OPERATING DATA OBTAINED DURING RUN 25 WITH DISSOLVING ZIRCALOY-2 PRESENT 
The over-all penetration rates obtained in this experiment were significantly lower than those from comparable runs made in the absence of dissolving Zircaloy -2 . For example, in the absence of zirconium, the specimens were often severed at the interface area. In the presence of zirconium, very little interface attack was noted except at one area on the the rmocouple well where about 9 mils of metal was removed ( 31 mils per month). Also, some thinning ( 7 to 23 mils per month) was noted at the interface on the straight coupon of the pair shown at the right in Figure 18.

Table 2 summarizes the penetration data obtained for eight different coupons or tubes. Weight-change data were taken on two coupon specimens. One specimen was raised periodically so that essentially a constant interface area was maintained as the liquid level rose. The corrosion rate was $0.7 \mathrm{mil}$ per month. The other specimen, fastened to the sparge tube, was not moved and the corrosion rate was $0.2 \mathrm{mil}$ per month.

The table also includes penetration values based on micrometer readings and on metallographic sections. The values reported are for areas where the major amount of attack was noted.

Figure 20a shows the microstructure of the INOR-8 thermocouple well at the interface area where maximum attack occurred. It can be seen that considerable roughening of the metal took place and that the wall thickness was decreased. A very slight amount of intergranular attack was noted. Figure $20 \mathrm{~b}$ shows the lesser amount of roughening which occurred on the metal immersed in the liquid.

Figure 21 a shows a section cut from the interface area of the movable, insulated coupon. A similar section from the movable, connected noninsulated coupon showed somewhat more roughening (see Figure $21 \mathrm{~b}$ ).

Two pieces of INOR -8 , overlapped about $1 / 2 \mathrm{in}$. and welded, were exposed in the bottom of the container. The assembly showed no major attack at any area, including the crevice. Approximately one-fourth of one side was covered with a deposit of crystals of zirconium.

This dissolution experiment demonstrated the effectiveness of dissolving metal in retarding the corrosion of container materials. The reasons for such inhibition are not entirely clear, at present. Low corrosion rates were measured for both connected and insulated specimens; hence, inhibition cannot be ascribed entirely to galvanic protection unless, of course, the efficacy of the insulation was negated by the bridging of "snow" between the container and the specimen support. Other factors such as a lower flow rate of $\mathrm{HF}$ in the effluent, due to its consumption by the hydrofluorination of the Zircaloy -2 , and a higher ratio of hydrogen to HF than had been studied previously, may have been equally important. 
TABEE 2. CORROSION OF INOR-\& AFTER 21 A-IIR EXPOSURE IN 700 C 43 MOLE PER CENT NAF -57 MOLE PER CENT LIF WITH DISSOLVING ZIRCALOY-2 (RUN 25)

\begin{tabular}{|c|c|c|c|c|c|}
\hline \multirow{3}{*}{ Specimen } & \multicolumn{3}{|c|}{ Penetration, mils per month } & \multirow[b]{3}{*}{ Visual Observations } & \multirow{3}{*}{ Metallographic Obsexvation } \\
\hline & \multirow{2}{*}{$\begin{array}{l}\text { From } \\
\text { Weight Loss }\end{array}$} & \multicolumn{2}{|c|}{ By Measurement (a) } & & \\
\hline & & Micrometer & Metallographic & & \\
\hline $\begin{array}{l}\text { Coupon attached to } \\
\text { insulated movable } \\
\text { thermocouple well }\end{array}$ & 0.7 & 1.7 & 2.6 & $\begin{array}{l}\text { Thin layer of metallic deposits on inmersed } \\
\text { portion; heavy etch at interface }\end{array}$ & $\begin{array}{l}\text { No intergranular attack; moderately } \\
\text { roughened surface }\end{array}$ \\
\hline \multirow[t]{2}{*}{$\begin{array}{l}\text { Insulated, movable, } \\
\text { thermocouple well }\end{array}$} & $\cdots$ & 31. & 31. & \multirow[t]{2}{*}{$\begin{array}{l}\text { Two loose chumps of crystals just above the } \\
\text { interface revealed heavily etched depressions } \\
\text { when removed; thin metallic deposits on } \\
\text { immersed portion }\end{array}$} & $\begin{array}{l}\text { Slight intergranuar atiack (about } \\
\text { 1 mil deep) at several places plus } \\
\text { moderately roughened surface on } \\
\text { interface section }\end{array}$ \\
\hline & $-\infty$ & $0.5^{(b)}$ & $0.0^{(b)}$ & & $\begin{array}{l}\text { No intergrantlar attack, slighel } \\
\text { roughened surface on section } 2 \text { in. } \\
\text { above bot tom of tube (liquid phase) }\end{array}$ \\
\hline $\begin{array}{l}\text { Coupon attached to } \\
\text { fixed sparge tube }\end{array}$ & 0.2 & 0.7 & -. & $\begin{array}{l}\text { Thin layer of metallic deposits on immersed } \\
\text { portion }\end{array}$ & \\
\hline Fixed sparge tube & -- & 0.0 & $\infty$ & $\begin{array}{l}\text { Some metallic deposits on immersed portion; } \\
\text { no apparent attack }\end{array}$ & \\
\hline \multirow[t]{2}{*}{$\begin{array}{l}\text { Straight coupon welded } \\
\text { to movable tube }\end{array}$} & $\infty$ & & $6.6^{(d)}$ & $\begin{array}{l}\text { Thin layer of metallic deposits on immersed } \\
\text { portion; heavy etch at interace; micrometer }\end{array}$ & \multirow[t]{4}{*}{$\begin{array}{l}\text { No intergranular attack; severely } \\
\text { roughened surface }\end{array}$} \\
\hline & -. & $0.3^{(e)}$ & $-\infty$ & $\begin{array}{l}\text { rate of } 23 \text { is for reduction in width at necked - } \\
\text { down edge }\end{array}$ & \\
\hline $\begin{array}{l}\text { Bent coupon welded to } \\
\text { movable tube }\end{array}$ & $\infty$ & 2.6 & - & $\begin{array}{l}\text { Thin layer of metallic deposits on immersed } \\
\text { portion; heavy etch at interface }\end{array}$ & \\
\hline Movable tube & - & 0.0 & - & Exposed in vapor only; no apparent attack & \\
\hline $\begin{array}{l}\text { Welded piece exposed } \\
\text { on the bottom of contamer }\end{array}$ & er & 0.5 & 0.9 & $\begin{array}{l}\text { Approximately one-fourh of one side was covered } \\
\text { with tightly adherem metallic-appearing crystals; } \\
\text { spectrographic analy sis indicated major constit- } \\
\text { uent of crystals was zirconiun with no tin present }\end{array}$ & $\begin{array}{l}\text { No intergranuar attack; no attack } \\
\text { at the crevice; slighty roughened } \\
\text { surface }\end{array}$ \\
\hline
\end{tabular}

(a) The micrometer and metallographic measurements were based on dimensional charges at sites of greatest at tack, except as noted.

(b) Measured 22 in. below interface.

(c) Measured across width of specimen.

(d) Measured across thickness of specimen.

(e) Measured $0.4 \mathrm{in}$. below interface. 


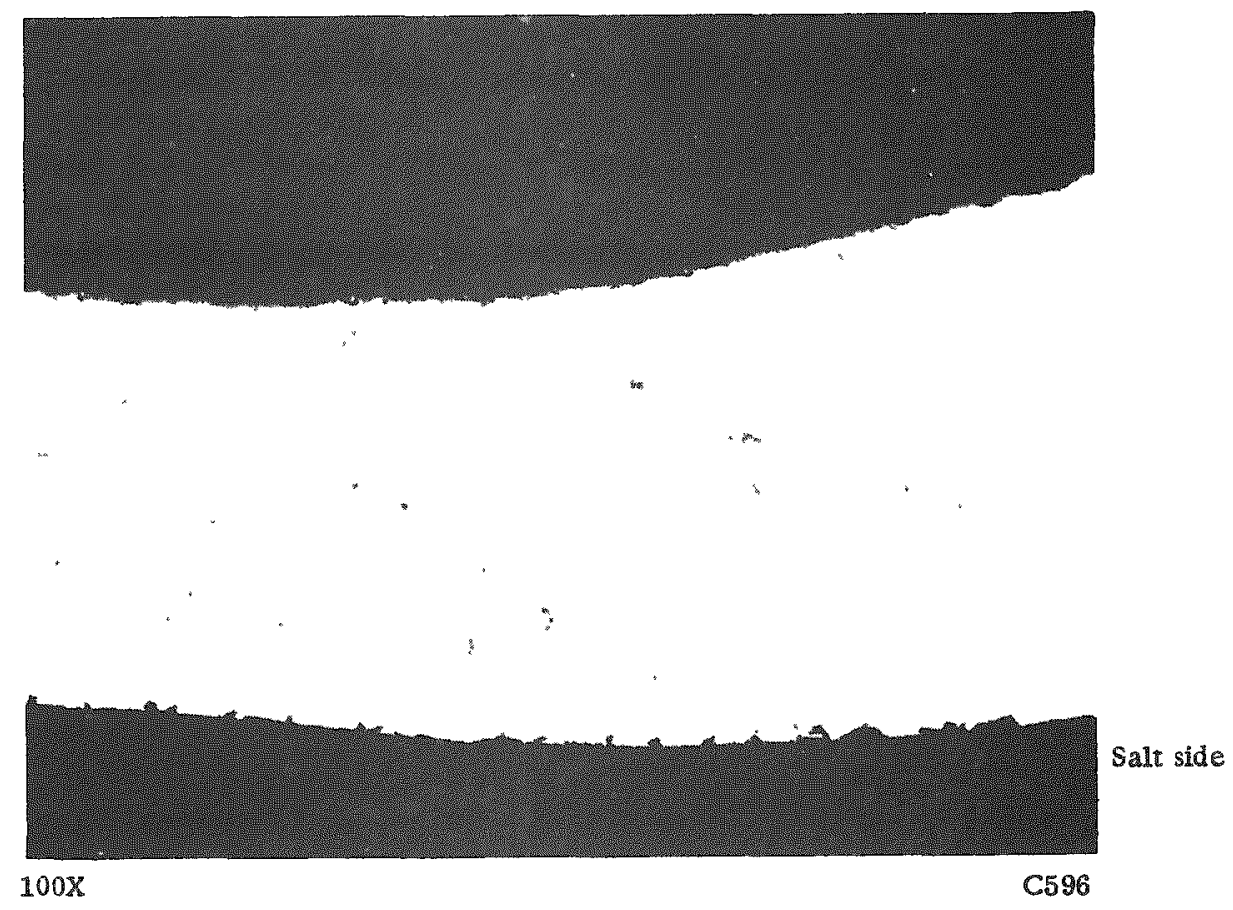

a. Interface, at Maxinum penetration

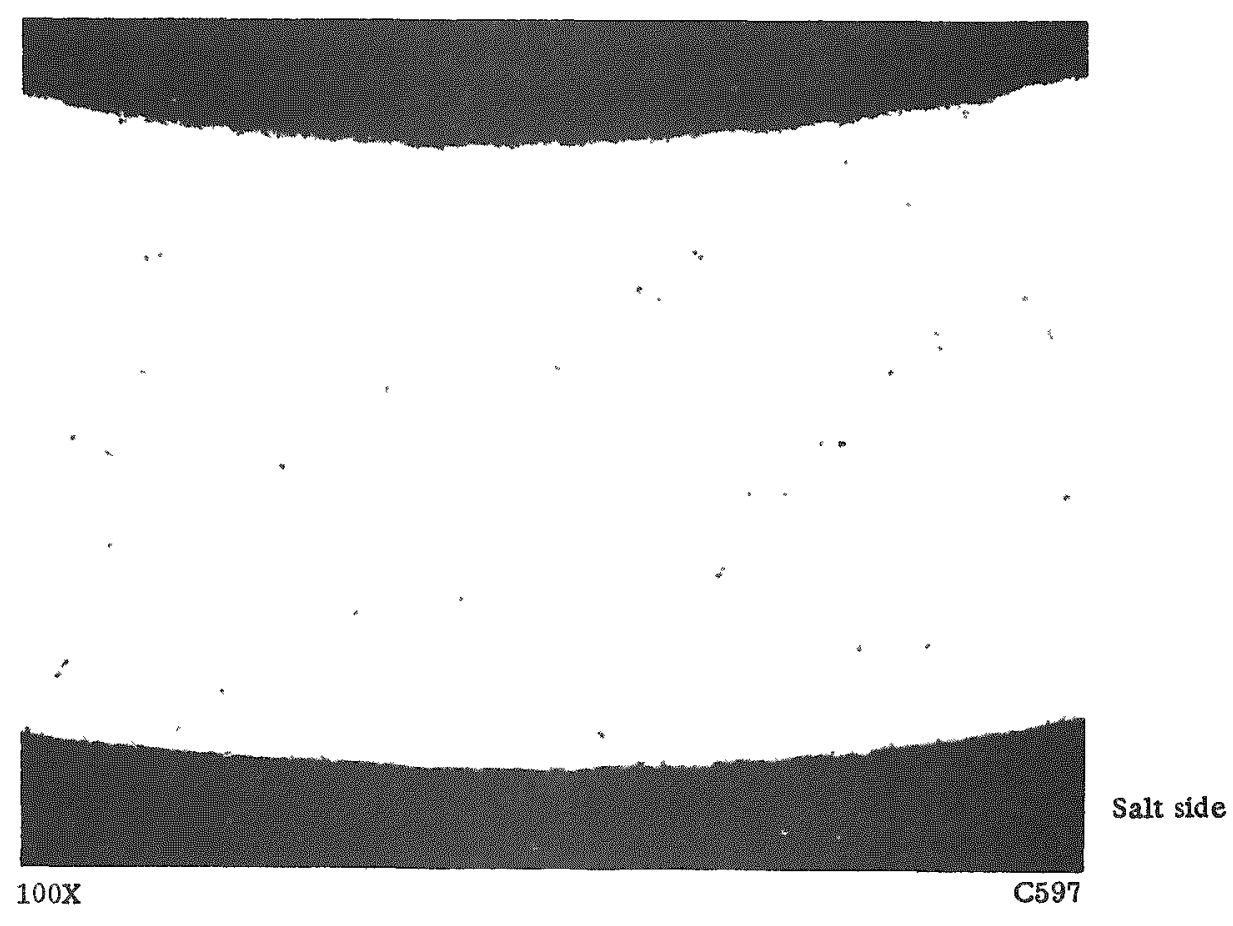

b. Liquid Portion, 2 In. From Botton of the Well

FIGURE 20. ATTACK ON INOR-8 THERMOCOUPLE WELL IN RUN 25 WITH DISSOLVING ZIRCALOY-2 PRESENT IN THE SALT 


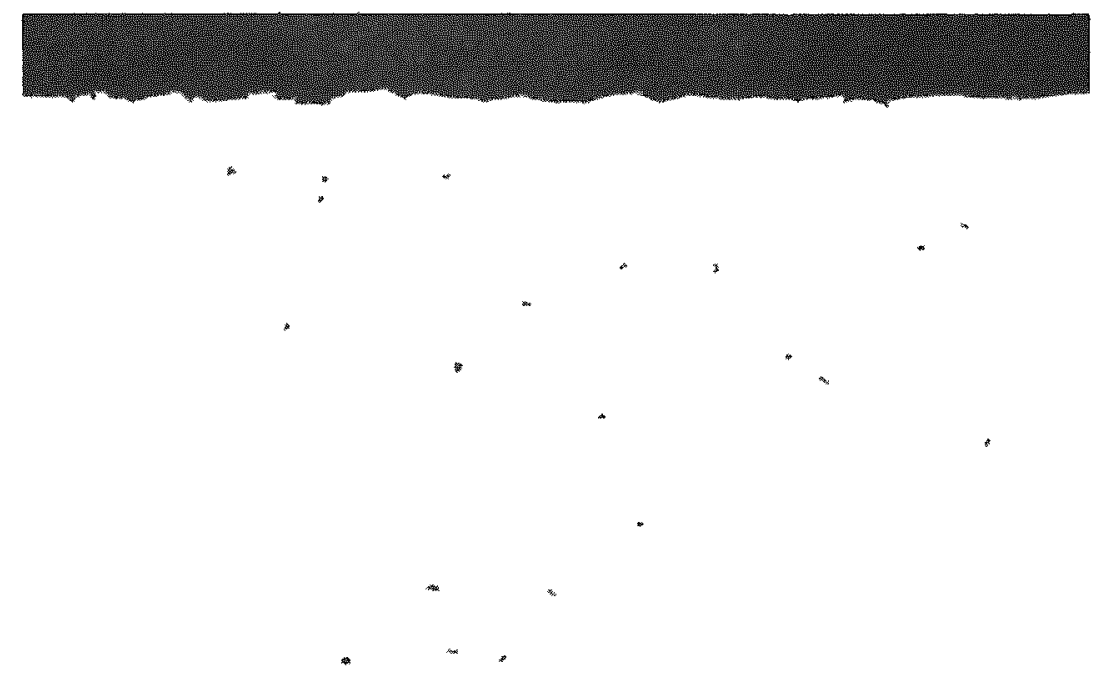

a. Movable, Insulated Coupon at the Interface

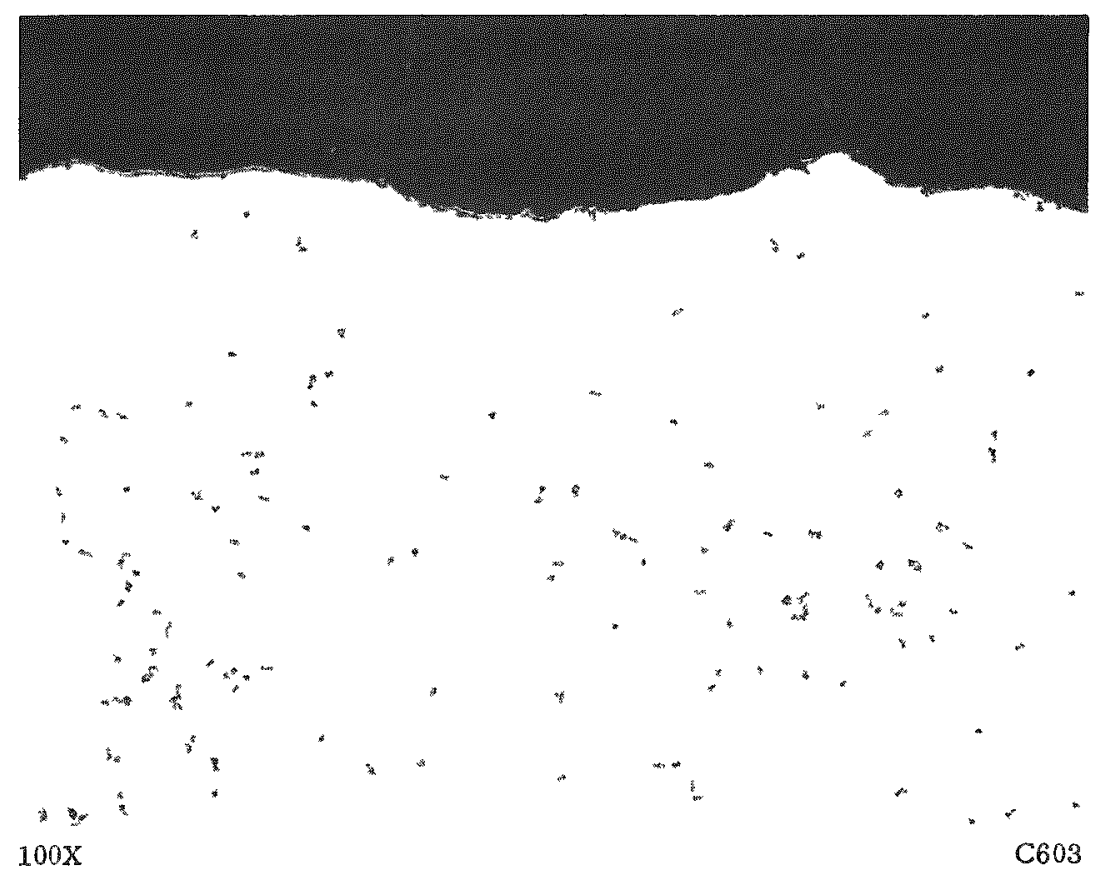

b. Movable, Connected Coupon at the Interface

FIGURE 21. ATTACK ON TWO INOR-8 COUPONS IN RUN 25 WITH DISSOLVING ZIRCALOY - 2 PRESENT IN THE SALT 


\section{CONCLUSIONS}

The areas most susceptible to damage in containers holding molten salt are located at interface positions. Work has shown that rapid failure can be anticipated at such spots, particularly at high temperatures and in mixtures high in alkali metal salts. Preliminary results indicate that the corrosive attack can be retarded appreciably by maintaining dissolution of zirconium at all times. However, even under these conditions some selective attack was still observed.

INOR -8 , INOR -1 , and Hastelloy $B$ have shown fairly good resistance to attack under the optimum conditions. However, Hastelloy $\mathrm{B}$ age hardens after prolonged use at the temperatures contemplated, and INOR-1 shows loss of molybdenum on unprotected outer surfaces. INOR -8 has been chosen as the most promising candidate material since it does not possess the above disadvantages and yet shows approximately the same resistance to corrosion as the other two alloys.

\section{ACKNOW LEDGMENT}

The authors greatly appreciated the continuous technical support that was received during the course of the research from the Chemical Technology Center at ORNL. They are especially grateful for the friendly help of W. E. Clark and R. P. Milford who closely followed the experimental work. Thanks also are due to G. I. Cathers, A. E. Goldman, and R. W. Horton of ORNL.

The keen interest of $\mathrm{H}$. A. Pray, who critically reviewed the program at regular intervals and the valuable support given by W. K. Boyd, G. L. Ericson, J. C. Vargo, W. N. Stiegelmeyer, and W. C. Baytos, all of Battelle, are appreciated.

PDM :CLP:OMS:EFS:FWF/mmk 
APPENDIX

SUMMAR Y OF CORROSION AND ANALYTICAL DATA 
The details of the operating conditions used with the Hastelloy B containers are summarized in Table A-1. Corrosion results for INOR -8 , INOR -1 , Hastelloy $B$, and silver are included in Table $\mathrm{A}-2$.

\section{Analytical Results}

$\underline{\text { Salt Analyses }}$

An analysis was made of each salt composition at the beginning and end of an experiment. Table A-3 summarizes the results obtained. The analyses were provided through the cooperation of ORNL chemists. It can be seen that, as might be expected, the major impurity in the salt from the Inconel containers (Runs 1 to 14 ) was chromium and the minor impurities were copper, iron, and nickel. In the Hastelloy B containers, the major impurity was nickel and smaller amounts of chromium, copper, iron, and molybdenum were found.

There is a fairly good correlation between the metal content of the salt and the corrosiveness of the exposure conditions as measured by the corrosion specimens. Longer exposure time increased the corrosion of the container as reflected in the salt analyses. More corrosive salt compositions showed higher metal pickup.

Some increase in sulfur content of the salt was noted with use.

\section{Effluent-Gas Analysis}

The amount of hydrogen present in the effluent gas should give some indication of the amount of corrosion taking place on the container walls and on the specimens. It was found that about $10 \mathrm{ml}$ per hr of hydrogen was evolved when a Hastelloy $\mathrm{B}$ container was used and about seven times more was evolved when an Inconel container was used. Thus, in general, these results agree fairly well with the corrosion results obtained by other procedures.

\section{HF Purity}

One major impurity sometimes associated with liquefied $H F$ is sulfur. It is believed that the sulfur canbe present as fluorosulfonic acid, as $\mathrm{H}_{2} \mathrm{~S}$, or possibly as other compounds. 
TABLE A-1. OPERATING CONDITIONS FOR CORROSION STUDIES IN HASTELLOX B CONTAINERS

\begin{tabular}{|c|c|c|c|c|c|c|c|}
\hline \multirow[b]{2}{*}{ Run } & \multirow{2}{*}{$\begin{array}{l}\text { Nominal Salt Composition, } \\
\text { mole per cent }\end{array}$} & \multicolumn{2}{|c|}{ Atmosphere, g per hr } & \multirow[b]{2}{*}{ Container } & \multirow{2}{*}{$\begin{array}{l}\text { UF } \\
\text { Tank }\end{array}$} & \multirow{2}{*}{$\begin{array}{c}\text { Temperature, } \\
\text { C }\end{array}$} & \multirow{2}{*}{$\begin{array}{l}\text { Time, } \\
\text { hr }\end{array}$} \\
\hline & & $\mathrm{HF}$ & Hydrogen & & & & \\
\hline 17 & $59 \mathrm{NaF}-41 \mathrm{ZnF}_{4}$ & 10 & $\infty$ & $12-1$ & FC 11197 & 650 & 504 \\
\hline $17 \mathrm{~A}$ & Salt remaining from Run 17 & 25 & -- & $12-1$ & FC 11197 & 650 & 507 \\
\hline 15 & $50 \mathrm{NaF}^{-50 \mathrm{ZnF}_{4}}$ & 10 & -- & $11-1$ & B & 650 & 500 \\
\hline $15 \mathrm{~A}$ & Salt remaining from Run 15 & 10 & - & $11-1$ & B & 650 & 510 \\
\hline 16 & $50 \mathrm{NaF}-50 \mathrm{ZnF}_{4}$ & 10 & 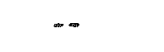 & $10-1$ & B & 650 & 505 \\
\hline $16 \mathrm{~A}$ & Salt remaining from Run 16 & 10 & $-\infty$ & $10-1$ & B & 650 & 510 \\
\hline 19 & $50 \mathrm{NaF}_{-}-50 \mathrm{ZrF}_{4}$ & 10 & 0.24 & $11-2$ & FC 11197 & 650 & 425 \\
\hline $19 A^{(a)}$ & Salt remaining from Run 19 & 10 & $-\infty$ & $11-2$ & FC 19874 & 650 & 479 \\
\hline $19 \mathrm{~B}$ & Salt remaining from Run $19 \mathrm{~A}$ & 10 & - & $11-2$ & FC 19874 & 650 & 200 \\
\hline $19 \mathrm{C}$ & Salt remaining from Run 198 & 10 & $\cdots$ & $11-2$ & FC 19874 & 700 & 200 \\
\hline 22 & $44 \mathrm{NaF}-56 \mathrm{ZrF}_{4}-0.1 \mathrm{UF}_{4}$ & 10 & 0.24 & $15-1$ & FC 19874 & 650 & 199 \\
\hline $22 \mathrm{~A}$ & Salt remaining from Run 22 & 10 & $-\infty$ & $1.5-1$ & FC 19874 & 650 & 200 \\
\hline 20 & $47 \mathrm{NaF}-53 \mathrm{LiF}$ & 10 & -- & $13-1$ & FC 11197 & 700 & 263 \\
\hline 21 & $45 \mathrm{NaF}-55 \mathrm{LiF}$ & 10 & 0.24 & $14-1$ & FC 11197 & 700 & 123 \\
\hline 24 & $43 \mathrm{NaF}-57 \mathrm{LiF}$ & 10 & $\cdots$ & $12-2$ & FC 19874 & 700 & 93 \\
\hline 18 & $19 \mathrm{NaF}-55 \mathrm{ZNF}_{4}-26 \mathrm{LF}=0.2 \mathrm{UF}_{4}$ & $\begin{array}{l}\text { Bad leak } \\
\text { nitrogen }\end{array}$ & & $10-2$ & None & 600 & 22 \\
\hline 23 & $19 \mathrm{NaF}-55 \mathrm{ZFF}_{4}-26 \mathrm{LiF}_{-0.2 \mathrm{UF}_{4}}$ & 10 & - & $16-1$ & FC 19874 & 600 & 200 \\
\hline $23 \mathrm{~A}$ & Salt remaining from Run 23 & 10 & $-\cdots$ & $16-1$ & FC 19874 & 650 & 200 \\
\hline $23 B$ & Salt remaining from Run $23 \mathrm{~A}$ & 10 & $\infty$ & $16-1$ & FC 19874 & 700 & 160 \\
\hline $25^{(b)}$ & $43 \mathrm{NaF}-57 \mathrm{LiF}$ & 10 & $-\infty$ & $14-2$ & FC 19874 & 700 & 214 \\
\hline
\end{tabular}

(a) In Run $19 \mathrm{~A}, 20 \mathrm{ppm}$ oxygen was added as air.

(b) Run 25 was conducted in presence of dissolving zirconium (Zircaloy-2). 
TABIE A -2, CORROSION RESULTS FROM HYDROFLUORINATION RUNS MADE IN HASTELLOY B CONTATNERS

\begin{tabular}{|c|c|c|c|c|c|c|c|}
\hline \multirow[b]{3}{*}{ Run } & \multirow{2}{*}{\multicolumn{3}{|c|}{ Specimen Description }} & \multicolumn{3}{|c|}{$\begin{array}{l}\text { Corrosion Rate Determined by } \\
\text { Method Shown, mils per month }\end{array}$} & \multirow[b]{3}{*}{ Appearance After Exposure } \\
\hline & & & & Weight & Micrometer & Metallographic & \\
\hline & Material & Type & Position & & & Section & \\
\hline \multirow[t]{10}{*}{17} & INOR -8 & $\begin{array}{l}\text { Impingement } \\
\text { tube }\end{array}$ & -- & 0.4 & -- & 2.9 & Light etch \\
\hline & INOR -8 & Coupon & Vapor & 0.4 & 0.0 & -- & Ditto \\
\hline & INOR -8 & Coupon & Interface $(a)$ & 6.3 & 16 & 23 & $\begin{array}{l}\text { Necked down } 11 \text { mils at } \\
\text { interface }\end{array}$ \\
\hline & INOR -8 & Coupon & Liquid & 0.6 & -- & - & Black, rough surface \\
\hline & INOR - 1 & $\begin{array}{l}\text { Impingement } \\
\text { tube }\end{array}$ & - & 0.03 & -- & 1.5 & Very light etch \\
\hline & INOR - 1 & Coupona & Vapor & 0.4 & 0.0 & $=$ & Light etch \\
\hline & INOR -1 & Couspon & Interface & 4.5 & 8.7 & 15 & $\begin{array}{l}\text { Necked down } 6 \text { mils at } \\
\text { interface }\end{array}$ \\
\hline & INOR -1 & Coupon & Liquid(a) & 2.5 & - & -- & Black, rough surface \\
\hline & $\$-816$ & Coupon & Liquid(a) & 3,4 & 10 & 12 & Thickness reduced $14 \mathrm{mils}$ \\
\hline & IIastelloy B & Coupon & Interface & 3.6 & 8.7 & 12 & $\begin{array}{l}\text { Necked down } 6 \text { mils at } \\
\text { interface }\end{array}$ \\
\hline \multirow[t]{12}{*}{$17 \mathrm{~A}$} & INOR -8 & $\begin{array}{l}\text { Impingement } \\
\text { tube }\end{array}$ & $-\infty$ & 2.2 & -- & -- & Light etch \\
\hline & INOR -8 & Iube & Interface & 15 & 45 & $-\infty$ & $\begin{array}{l}\text { Necked down } 31 \text { mils at } \\
\text { interface }\end{array}$ \\
\hline & INOR -8 & Coupon & Vapor & 0.25 & -- & $-\infty$ & Light etch \\
\hline & INOR -8 & Coupon & Interface & 28 & $=$ & -- & Severed at interface \\
\hline & INOR -8 & Coupon & Liquid & 4.5 & -- & -- & Moderate etch \\
\hline & INOR - 1 & $\begin{array}{l}\text { Impingement } \\
\text { tube }\end{array}$ & -- & 0.1 & -- & -- & Very light etch \\
\hline & INOR -1 & Tube & Interface & 5.0 & 16 & $-\infty$ & $\begin{array}{l}\text { Necked down } 11 \text { mils at } \\
\text { interface }\end{array}$ \\
\hline & INOR - 1 & Coupon & Vapor & 0.31 & -- & -- & Moderate etch \\
\hline & INOR -1 & Coupon & Interface & 20 & $-\infty$ & $=$ & Severed at interface \\
\hline & INOR -1 & Coupon & Liquid & 7.9 & -- & $-\infty$ & Moderate to heavy etch \\
\hline & Hastelloy $\mathrm{B}$ & Coupon & Interface & 11.7 & -- & -- & Severed at interface \\
\hline & Hastelloy W & Tube & -- & -- & -- & -- & Ditto \\
\hline 15 & INOR-8 & $\begin{array}{l}\text { Impingement } \\
\text { tube }\end{array}$ & -- & 1.2 & -- & - & Light etch \\
\hline \multirow[t]{2}{*}{$15 \mathrm{~A}$} & INOR -8 & $\begin{array}{l}\text { Impingement } \\
\text { tube }(b)\end{array}$ & -- & 1.5 & -- & 1.7 & Heavy etch \\
\hline & TNOR-8 & Tube & Vapur & 0.5 & -- & 1.4 & Slight pitting: light etch \\
\hline 16 & INOR - 1 & $\begin{array}{l}\text { Impingernent } \\
\text { tube }\end{array}$ & $-\infty$ & 2.1 & -- & -- & Heavy etch \\
\hline \multirow[t]{2}{*}{$16 \mathrm{~A}$} & INOR -1 & $\begin{array}{l}\text { Impingement } \\
\text { tube }\end{array}$ & - & 1.7 & -- & 5.2 & Crystal deposits \\
\hline & INOR-1 & Tube & Vapor & 1.5 & - & 3.9 & Light etch \\
\hline \multirow[t]{9}{*}{19} & INOR -8 & $\begin{array}{l}\text { Impingement } \\
\text { tube }\end{array}$ & $-\infty$ & 0.09 & - & 2.2 & Tarnish film \\
\hline & INOR -8 & Coupon & Vapor & 0.35 & -- & - & Light etch \\
\hline & INOR -8 & Coupon & Interface & 0.18 & -- & 0.86 & Ditto \\
\hline & TNOR -8 & Coupon & Liquid & 0.35 & -- & $-\infty$ & Ditto \\
\hline & INOR - 1 & $\begin{array}{l}\text { Impingement } \\
\text { tube }\end{array}$ & - & 0.003 & $-\infty$ & 0.86 & Tarnish film \\
\hline & LNOR -1 & Coupon & Vapor & 0.11 & -- & -- & Light etch \\
\hline & INOR - 1 & Coupon & Interface & 1.3 & -- & 2.2 & Ditto \\
\hline & INOR - I & Coupon & Liquid & 1.9 & -- & - & Moderate etch \\
\hline & Hastelloy B & Coupon & Interface & 0.8 & $\cdots$ & -- & Light to moderate etch \\
\hline
\end{tabular}


TABLE A-2. (Continued)

\begin{tabular}{|c|c|c|c|c|c|c|c|}
\hline \multirow[b]{3}{*}{ Run } & \multirow{2}{*}{\multicolumn{3}{|c|}{ Specimen Description }} & \multicolumn{3}{|c|}{$\begin{array}{l}\text { Corrosion Rate Determined by } \\
\text { Method Shown, mils per month }\end{array}$} & \multirow[b]{3}{*}{ Appearance After Exposure } \\
\hline & & & & \multirow{2}{*}{$\begin{array}{l}\text { Weight } \\
\text { Loss }\end{array}$} & \multirow{2}{*}{$\begin{array}{l}\text { Micrometer } \\
\text { Measurement }\end{array}$} & \multirow{2}{*}{$\begin{array}{l}\text { Metallographic } \\
\text { Section }\end{array}$} & \\
\hline & Material & Type & Position & & & & \\
\hline \multirow[t]{11}{*}{$19 \mathrm{~A}$} & INOR-8 & $\begin{array}{l}\text { Impingement } \\
\text { tube }\end{array}$ & -- & 1.5 & - & -- & Light etch \\
\hline & INOR -8 & Tube & Interface & 3.5 & -- & -- & Moderate etch \\
\hline & INOR -8 & Coupon & Vapor & 0.36 & -. & -- & Light etch \\
\hline & INOR -8 & Coupon & Interface & 4.3 & 14 & $-\infty$ & $\begin{array}{l}\text { Necked down } 9 \text { mils at } \\
\text { interface }\end{array}$ \\
\hline & LNOR -8 & Coupon & Liquid & 5.9 & -- & -- & Moderate etch \\
\hline & INOR - 1 & $\begin{array}{l}\text { Impingement } \\
\text { tube }\end{array}$ & -- & 1.0 & - & -- & Light etch \\
\hline & INOR - 1 & Tube & Interface & 4.2 & 6.7 & -- & $\begin{array}{l}\text { Necked down } 4.4 \text { mils at } \\
\text { interface }\end{array}$ \\
\hline & INOR-1 & Coupon & Vapor & 0.34 & $-\infty$ & $-\infty$ & Light etch \\
\hline & INOR - I & Coupon & Tnterface & 3.6 & 9.1 & -- & $\begin{array}{l}\text { Necked down } 6 \text { mils at } \\
\text { interface }\end{array}$ \\
\hline & INOR -1 & Coupon & Liquid & 4.4 & -- & $-\infty$ & $\begin{array}{l}\text { Metallic deposits; moderate } \\
\text { etch }\end{array}$ \\
\hline & Hastelloy B & Conpon & Interface & 1.2 & -- & -- & Moderate etch \\
\hline \multirow[t]{4}{*}{$19 \mathrm{~B}$} & INOR -8 & Coupon & Interface & 13 & 21 & - & $\begin{array}{l}\text { Necked down } 5.8 \text { mils at } \\
\text { interface }\end{array}$ \\
\hline & INOR -1 & $\begin{array}{l}\text { Impingement } \\
\text { tube }\end{array}$ & - & 0.42 & - & - & Crystal deposits \\
\hline & INOR - 1 & Coupon & Interface & 17 & 38 & -- & $\begin{array}{l}\text { Necked down } 10 \text { mils at } \\
\text { interface }\end{array}$ \\
\hline & Fastelloy B & Coupon & Intexface & 3.0 & 6.2 & -- & $\begin{array}{l}\text { Necked down } 1.7 \mathrm{mils} \text { at } \\
\text { interface }\end{array}$ \\
\hline \multirow[t]{11}{*}{$19 \mathrm{C}$} & INOR -8 & $\begin{array}{l}\text { Impingernent } \\
\text { tube }\end{array}$ & -- & 5.7 & -- & $-\infty$ & Heavy etch \\
\hline & INOR -8 & Tube & Interface & Weight & $\sin$ & & Crystal deposits; light etch \\
\hline & INOR -8 & Coupon & Vapor & 1.2 & $-\infty$ & $-\infty$ & Ditto \\
\hline & INOR -8 & Coupon & Interface & 29 & -- & -- & Necked down at interface \\
\hline & INOR -8 & Coupon & Liquid & 17 & - & -- & Heavy etch \\
\hline & INOR-1 & $\begin{array}{l}\text { Impingement } \\
\text { tube }\end{array}$ & -- & 3.4 & $-\cdots$ & -- & Moderate etch \\
\hline & INOR - 1 & Coupon & Vapor & 0.76 & -- & -- & Crystal deposits; light etch \\
\hline & INOR - 1 & Coupon & Interface & 21 & -- & -- & $\begin{array}{l}\text { Necked down at interface; } \\
\text { crystal deposits }\end{array}$ \\
\hline & INOR -1 & Coupon & Liquid & 17 & -- & -- & Crystal deposits; heavy etch \\
\hline & Hastelloy $B$ & Coupon & Interface & 14 & $-\infty$ & -- & $\begin{array}{l}\text { Necked down at interface; } \\
\text { crystal deposits }\end{array}$ \\
\hline & Silver & Coupon & Interface & 8.5 & -- & -- & $\begin{array}{l}\text { Necked down slightly at } \\
\text { interface }\end{array}$ \\
\hline \multirow[t]{10}{*}{22} & INOR -8 & $\begin{array}{l}\text { Impingement } \\
\text { tube }\end{array}$ & -- & 0.01 & -- & -- & Tarnish film \\
\hline & INOR -8 & Coupon & Vapor & 0.16 & -- & -- & Ditto \\
\hline & INOR -8 & Coupon & Interface & 0.39 & -- & 2.9 & $\begin{array}{l}\text { Ditto, plus interface penetra- } \\
\text { tion of } 0.8 \mathrm{mils}\end{array}$ \\
\hline & INOR -8 & Coupon & Liquid & 0.84 & -- & -- & Tarnish film \\
\hline & INOR - 1 & $\begin{array}{l}\text { Impingement } \\
\text { tube }\end{array}$ & -- & Weight & ain & & Ditto \\
\hline & INOR-1 & Tube & Interface & 0.32 & - & -- & Ditto, plus some light etch \\
\hline & INOR - 1 & Coupon & Vapor & 0.08 & 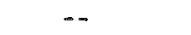 & $-\infty$ & Dark tarnish film \\
\hline & INOR -1 & Coupon & Interface & 0.35 & -- & -.. & Ditto \\
\hline & INOR -1 & Coupon & Liquid & 0.61 & -- & -- & Ditto \\
\hline & Hastelloy B & Coupon & Interface & 0.26 & -- & -- & Tarnish film \\
\hline
\end{tabular}


TABLE A-2. (Continued)

\begin{tabular}{|c|c|c|c|c|c|c|c|}
\hline \multirow[b]{3}{*}{ Run } & \multirow{2}{*}{\multicolumn{3}{|c|}{ Specimen Description }} & \multicolumn{3}{|c|}{$\begin{array}{l}\text { Corrosion Rate Determined by } \\
\text { Method Shown, mils per month }\end{array}$} & \multirow[b]{3}{*}{ Appearance After Exposure } \\
\hline & & & & Weight & Micrometer & Metallographic & \\
\hline & Material & Type & Postion & Loss & Measurement & Section & \\
\hline \multirow[t]{9}{*}{$22 \mathrm{~A}$} & INOR -8 & Coupons & Vapor & 0.44 & -- & $-\infty$ & $\begin{array}{l}\text { Some silver deposits, light } \\
\text { etch }\end{array}$ \\
\hline & INOR -8 & Coupon & Interface & 4.5 & 4.0 & - & $\begin{array}{l}\text { Loosely adherent dark pow- } \\
\text { der; necked down } 1.1 \text { mils } \\
\text { at interface }\end{array}$ \\
\hline & INOR -8 & Coupon & Liquid & 3.7 & -- & -- & Some silver deposits \\
\hline & INOR - 1 & $\begin{array}{l}\text { Inzpingement } \\
\text { tube }\end{array}$ & -- & 0.63 & -- & -- & $\begin{array}{l}\text { Metallic coat plus crystal } \\
\text { deposits }\end{array}$ \\
\hline & INOR - 1 & Coupon & Vapor & 0.34 & $-\infty$ & -- & $\begin{array}{l}\text { Some silver deposits, light } \\
\text { etch }\end{array}$ \\
\hline & INOR -1 & Coupon & Interface & 3.6 & 4.0 & -- & $\begin{array}{l}\text { Loosely adherent dark pow- } \\
\text { der; necked down 1.l mils } \\
\text { at interface }\end{array}$ \\
\hline & INOR - 1 & Coupon & Liquid & 5.0 & -- & -- & Moderate etch \\
\hline & Hasteiloy $\mathrm{B}$ & Coupon & Interface & 2.6 & 5.1 & -- & $\begin{array}{l}\text { Loosely adherent dark pow- } \\
\text { der; necked down } 1.4 \text { mils } \\
\text { at interface }\end{array}$ \\
\hline & Silver & Coupon & Interface & 6.5 & 58 & -- & $\begin{array}{l}\text { Necked down } 16 \text { mils at } \\
\text { interface }\end{array}$ \\
\hline \multirow[t]{10}{*}{20} & INOR -8 & $\begin{array}{l}\text { Impingement } \\
\text { tube }\end{array}$ & -- & 9.0 & $-\infty$ & $-\infty$ & Crystal deposits; heavy etch \\
\hline & TNOR -8 & Tube & Interface & Severed & & -- & Severed at interface \\
\hline & INOR -8 & Coupon & Vapor & 7.2 & -- & -- & Heavy etch \\
\hline & INOR -8 & Coupon & Interface & Severed & & $-\infty$ & Severed at interface \\
\hline & INOR -8 & Coupon & Liquid & 20 & -- & 28 & Heavy etch \\
\hline & INOR-1 & $\begin{array}{l}\text { Impingement } \\
\text { tube }\end{array}$ & -- & 2.9 & -- & -- & $\begin{array}{l}\text { Numerous small pits; } \\
\text { moderate etch }\end{array}$ \\
\hline & INOR-1 & Coupon & Vapor & 1.7 & -- & -- & Some severe etch \\
\hline & INOR -1 & Coupon & Interface & Severed & & & Severed at interface \\
\hline & INOR - 1 & Coupon & Liquid & 17 & -- & -- & Moderate etch \\
\hline & Hastelloy $\mathrm{B}$ & Coupon & Interface & Severed & & & Severed at interface \\
\hline \multirow[t]{10}{*}{21} & INOR -8 & $\begin{array}{l}\text { Impingement } \\
\text { tube }\end{array}$ & -- & - & -- & & Thick crystal deposits \\
\hline & LNOR -8 & 'Tube & Interface & -- & -- & & $\begin{array}{l}\text { Hedvy crystal deposit; heavy } \\
\text { etch; attacked in liquid }\end{array}$ \\
\hline & INOR -8 & Coupon & Vapor & 0.11 & -- & -- & Light etch \\
\hline & INOR -8 & Coupon & Interface & -- & -- & & Crystal deposits; heavy etch \\
\hline & INOR -8 & Coupon & Liquid & 30 & $-\infty$ & $-\infty$ & Heavy etch \\
\hline & INOR -1 & $\begin{array}{l}\text { Impingem ent } \\
\text { tube }\end{array}$ & $-\infty$ & -- & $\cdots$ & & $\begin{array}{l}\text { Many loosely adherent crystal } \\
\text { deposits; light etch }\end{array}$ \\
\hline & INOR -1 & Coupon & Vapor & 0.02 & -- & -- & Mottled tarnish film \\
\hline & INOR -1 & Coupon & Interface & Severed & & & Severed at interface \\
\hline & INOR -1 & Coupon & Liquid & -- & - & & $\begin{array}{l}\text { Loosely adherent crystal de - } \\
\text { posits; heavy etch }\end{array}$ \\
\hline & Hastelloy $\mathrm{B}$ & Coupon & Interface & Severed & & & Severed at interface \\
\hline \multirow[t]{9}{*}{24} & INOR - 8 & $\begin{array}{l}\text { Impingement } \\
\text { tabe }\end{array}$ & -- & 18 & -- & -- & Heavy etch \\
\hline & INOR -8 & Tube & Interface & 48 & - & -- & Necked down at interface \\
\hline & INOR -8 & Coupon & Vapox & 7.6 & .. & $-\infty$ & Crystal deposit; heavy etch \\
\hline & TNOR -8 & Coupon & Interface & 60 & -- & 100 & Necked down at interface \\
\hline & INOR -8 & Coupon & Liquiad & 43 & -- & -. & Heavy etch \\
\hline & INOR - I & $\begin{array}{l}\text { Impingernent } \\
\text { tube }\end{array}$ & $-\infty$ & 18 & - & -- & $\begin{array}{l}\text { Crystal deposits; moderate } \\
\text { etch }\end{array}$ \\
\hline & INOR-1 & Coupon & Vapor & 13 & - & -- & Heavy etch \\
\hline & INOR -1 & Coupon & Interface & 64 & - & 120 & Necked down at interface \\
\hline & INOR - 1 & Coupon & Liquid & 38 & $\ldots$ & -- & Heavy etch \\
\hline
\end{tabular}


T ABLE A-2. (Continued)

\begin{tabular}{|c|c|c|c|c|c|c|c|}
\hline \multirow[b]{3}{*}{ Run } & \multirow{2}{*}{\multicolumn{3}{|c|}{ Specimen Description }} & \multicolumn{3}{|c|}{$\begin{array}{l}\text { Corrosion Rate Determined by } \\
\text { Method Shown, mils per month }\end{array}$} & \multirow[b]{3}{*}{ Appearance After Exposure } \\
\hline & & & & \multirow{2}{*}{$\begin{array}{l}\text { Weight } \\
\text { Ioss }\end{array}$} & \multirow{2}{*}{$\begin{array}{l}\text { Micrometer } \\
\text { Measurement }\end{array}$} & \multirow{2}{*}{$\begin{array}{l}\text { Metallographic } \\
\text { Section }\end{array}$} & \\
\hline & Material & Type & Position & & & & \\
\hline \multirow[t]{9}{*}{23} & INOR -8 & $\begin{array}{l}\text { Tmpingenent } \\
\text { tube }\end{array}$ & - & $0.7+\frac{1}{3}$ & $-\cdots$ & $-\infty$ & Light etch \\
\hline & INOR -8 & Coupon & Vapor & 0.43 & $-\infty$ & $-\infty$ & Ditto \\
\hline & INOR -8 & Coupon & Taterface & 1.0 & -- & -- & Ditto \\
\hline & NOR -8 & Coupon & Liquid & 2.5 & -- & -- & Ditto \\
\hline & $\mathrm{TNOR}-1$ & $\begin{array}{l}\text { Impingement } \\
\text { tube }\end{array}$ & -- & 0.61 & -- & $=-$ & Ditio \\
\hline & TNOR-1 & Coupon & Vapor & 0.24 & $-\infty$ & -- & Ditto \\
\hline & INOR - 1 & Coupon & Inter face & 0.76 & $-\cdots$ & $-\infty$ & Ditto \\
\hline & INOR - 1 & Coupon & Liquid & 1.7 & -- & -- & Ditto \\
\hline & Hastelloy $\mathrm{B}$ & Coupon & Interface & 1.7 & $=-m$ & -- & Ditto \\
\hline \multirow[t]{9}{*}{$23 \mathrm{~A}$} & INOR-8 & $\begin{array}{l}\text { Impingkrnent } \\
\text { tube }\end{array}$ & & 0.63 & -- & -- & Tarnish film \\
\hline & INOR -8 & Coupon & Vapor & 1.1 & -- & -- & Light etch \\
\hline & $\operatorname{INOR}-8$ & Coupon & Interface & 4.6 & -- & -- & Moderate etch \\
\hline & TNOR -8 & Coupon & Liquid & 4.2 & -- & $-\infty$ & Ditto \\
\hline & INOR - 1 & $\begin{array}{l}\text { Impingernent } \\
\text { tube }\end{array}$ & -- & 0.23 & -- & - & Tarnish film \\
\hline & INOR - 1 & Coupon & Vapor & 0.55 & -- & -- & Ditto, plus light etch \\
\hline & INOR - 1 & Coupon & Interface & 3.3 & -- & -- & Moderate etch \\
\hline & $\operatorname{INOR}-1$ & Coupon & Iiquid & 4.4 & -- & - & Ditto \\
\hline & Hastelloy $B$ & Coupon & Tnterface & 2.1 & -- & -- & Ditto \\
\hline \multirow[t]{9}{*}{233} & INOR - 8 & $\begin{array}{l}\text { Impingement } \\
\text { tube }\end{array}$ & $-\infty$ & 1.1 & -- & -- & Light etch \\
\hline & INOR - 8 & Coupon & Vapor & 2.4 & -- & - & Ditto \\
\hline & INOR -8 & Coupon & Interface & 13 & 20 & $-\infty$ & $\begin{array}{l}\text { Necked down } 4.4 \text { mils at } \\
\text { interface }\end{array}$ \\
\hline & INOR -8 & Coupon & Liquid & 15 & -- & -- & Heavy etch \\
\hline & INOR-1 & $\begin{array}{l}\text { Impingenent } \\
\text { tube }\end{array}$ & -- & 0.36 & - & - & $\begin{array}{l}\text { Some crystal deposits; light } \\
\text { etch }\end{array}$ \\
\hline & INOR - 1 & Coupon & Vapox & 1.3 & $=-$ & $-\infty$ & Light etch \\
\hline & INOR - 1 & Coupon & Interface & 13 & 22 & - & $\begin{array}{l}\text { Necked down } 4.8 \text { mils at } \\
\text { interface }\end{array}$ \\
\hline & INOR - 1 & Coupon & Isiquid & 11 & $-\infty$ & $-\infty$ & Heavy etch \\
\hline & Hastelloy B & Coupon & Interface & 3.9 & 15 & $=-$ & $\begin{array}{l}\text { Necked down } 3.2 \text { mils at } \\
\text { interface }\end{array}$ \\
\hline \multirow[t]{5}{*}{25} & INOR -8 & Coupon & $\begin{array}{l}\text { Interface, movable } \\
\text { for constant } \\
\text { interface position }\end{array}$ & -- & $23^{(c)}$ & $6.8^{(d)}$ & $\begin{array}{l}\text { Necked down } 6.7 \text { mils on one } \\
\text { edge at interface; thin } \\
\text { metallic coating on liquid } \\
\text { portion }\end{array}$ \\
\hline & INOR -8 & Bent coupon & $\begin{array}{l}\text { Interface, movable } \\
\text { for constant } \\
\text { interface position }\end{array}$ & -- & 2.7 & - & $\begin{array}{l}\text { Necked down } 0.8 \text { mil about } \\
1-1 / 2 \text { in. above interface; } \\
\text { thin metallic coating on } \\
\text { liquid portion }\end{array}$ \\
\hline & INOR -8 & Coupon & $\begin{array}{l}\text { Tnterface, insulated, } \\
\text { movable for con- } \\
\text { stant interface } \\
\text { position }\end{array}$ & 0.73 & 1.7 & 2.7 & $\begin{array}{l}\text { Necked down } 0.5 \text { mil at } \\
\text { interface; thin metallic } \\
\text { coating on liquid portion }\end{array}$ \\
\hline & INOR -8 & Coupon & $\begin{array}{l}\text { Interface, fixed } \\
\text { position }\end{array}$ & 0.15 & 0.68 & $-\infty$ & $\begin{array}{l}\text { Necked down } 0.2 \text { mil at one } \\
\text { area; actual increase on } \\
\text { other areas; thin metallic } \\
\text { coating; light etch }\end{array}$ \\
\hline & INOR -8 & I ube & $\begin{array}{l}\text { Thermocouple well, } \\
\text { insulated }\end{array}$ & $-\infty$ & 31 & 31 & $\begin{array}{l}\text { Localized attack about } 9 \text { mils } \\
\text { deep near interface }\end{array}$ \\
\hline
\end{tabular}

(a) Support tube severed. Specimen remained in container during Run 17A. Thermocouple well and gas-inlet tube also severed.

(b) Total exposure was about $1000 \mathrm{hr}$ since this tube was used in run bove.

(c) Based on change in width.

(d) Based on change in thickness. 
TABLE A-3. ANALYSIS OF SALT COMPOSITIONS

\begin{tabular}{|c|c|c|c|c|c|c|c|c|c|c|c|c|}
\hline \multirow[b]{2}{*}{ Run } & \multirow[b]{2}{*}{ Condation } & \multicolumn{11}{|c|}{ Salt Analysis } \\
\hline & & $\begin{array}{l}\mathrm{Li}, \\
\mathrm{w} / \mathrm{o}\end{array}$ & $\begin{array}{l}\text { Na, } \\
\text { w/o }\end{array}$ & $\begin{array}{l}\mathrm{Zr}, \\
\mathrm{w} / \mathrm{O}\end{array}$ & $\begin{array}{l}F \\
W / 0\end{array}$ & $\begin{array}{c}\mathrm{U}, \\
\text { w/o }\end{array}$ & $\begin{array}{l}\mathrm{Cr}_{\mathrm{g}} \\
\mathrm{ppm}\end{array}$ & $\begin{array}{l}\mathrm{Ni}, \\
\text { ppm }\end{array}$ & $\begin{array}{l}\text { Fe, } \\
\text { ppm }\end{array}$ & $\begin{array}{l}\text { Cu, } \\
\text { ppm }\end{array}$ & $\begin{array}{l}\text { Mo. } \\
\text { ppm }\end{array}$ & $\begin{array}{c}\mathrm{S} \\
\mathrm{ppm}\end{array}$ \\
\hline 1 & Begannang & -- & 11.9 & 39.7 & 42.5 & -- & 55 & 120 & $\infty$ & 24 & $<10$ & $24,29,27$ \\
\hline 2 & Reused & - & $-\infty$ & - & $-\infty$ & -- & -- & $-\infty$ & $-\infty$ & -- & $-\infty$ & - \\
\hline 3 & $\begin{array}{l}\text { Reused } \\
\text { Final }\end{array}$ & $=$ & $\begin{array}{c}-\infty \\
13.3\end{array}$ & $4 \overline{41.5}$ & $-\infty \overline{45.4}$ & $=$ & $5,-\overline{835}$ & -- & $\overline{1,300}$ & $-\infty$ & - & $-\infty$ \\
\hline 4 & $\begin{array}{l}\text { Beginning } \\
\text { Final }\end{array}$ & -- & $\begin{array}{c}10.7 \\
--\end{array}$ & $\begin{array}{c}36.2 \\
-.-\end{array}$ & 41.7 & -- & ${ }_{-}^{65}$ & ${ }_{--}^{21}$ & 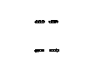 & - & $<10$ & $\begin{array}{l}17,17,22 \\
69,69\end{array}$ \\
\hline 5 & $\begin{array}{l}\text { Beginanng } \\
\text { Final }\end{array}$ & -- & $\begin{array}{c}12.8 \\
--\end{array}$ & $\begin{array}{c}39.4 \\
\ldots-\end{array}$ & $\begin{array}{c}44.8 \\
--\end{array}$ & - & $-{ }_{-}^{55}$ & $\begin{array}{r}80 \\
--\end{array}$ & $=$ & 23 & $\begin{array}{l}<10 \\
-\infty\end{array}$ & $\begin{array}{l}28,51,65 \\
48,44\end{array}$ \\
\hline 0 & $\begin{array}{l}\text { Beginning } \\
\text { Final }\end{array}$ & -- & $\begin{array}{l}12.4 \\
13.7\end{array}$ & $\begin{array}{l}38.7 \\
41.2\end{array}$ & $\begin{array}{l}42.7 \\
45.6\end{array}$ & $\overline{--}$ & $\begin{array}{r}105 \\
4,095\end{array}$ & $\begin{array}{l}<10 \\
165\end{array}$ & $-\overline{930}$ & $\begin{array}{l}28 \\
--\end{array}$ & $\begin{array}{r}<10 \\
5\end{array}$ & $31,37,28$ \\
\hline 7 & $\begin{array}{l}\text { Beginning } \\
\text { Final }\end{array}$ & -- & $\begin{array}{l}12.4 \\
13.8\end{array}$ & $\begin{array}{r}41.8 \\
+1.2\end{array}$ & $\begin{array}{l}42.6 \\
45.7\end{array}$ & -- & $\begin{array}{r}60 \\
4,930\end{array}$ & $\begin{array}{l}200 \\
135\end{array}$ & -- & $\begin{array}{l}32 \\
--\end{array}$ & $-<1$ & $35,26,28$ \\
\hline 9 & Beginning & -- & 11.4 & 43.5 & 45.4 & -- & 145 & 110 & 200 & -- & - & 6 \\
\hline 11 & Final & -- & 8.1 & 46.0 & 45.1 & - & 5,000 & 815 & 1,265 & -- & 110 & $61,50,55$ \\
\hline 10 & $\begin{array}{l}\text { Beginnung } \\
\text { Final }\end{array}$ & -- & $\begin{array}{l}13.8 \\
14.3\end{array}$ & $\begin{array}{l}41.2 \\
38.1\end{array}$ & $\begin{array}{l}45.7 \\
44.3\end{array}$ & $=$ & $\begin{array}{r}4,930 \\
23.500\end{array}$ & $\begin{array}{l}135 \\
850\end{array}$ & $\overline{4,760}$ & - & $-{ }_{2}$ & $90,86^{--} 81$ \\
\hline 12 & $\begin{array}{l}\text { Betginning } \\
\text { Final }\end{array}$ & -- & $\begin{array}{r}10.9 \\
8.8\end{array}$ & $\begin{array}{l}43.8 \\
43.5\end{array}$ & $\begin{array}{l}45.0 \\
43.8\end{array}$ & $=$ & $\begin{array}{r}5 \\
20,800\end{array}$ & $\begin{array}{r}40 \\
16,800\end{array}$ & $\begin{array}{l}160 \\
460\end{array}$ & - & $-{ }_{10}$ & $\begin{array}{l}28,35 \\
33,42\end{array}$ \\
\hline 14 & Final & -- & 11.4 & 43.5 & 44.8 & -- & 4,400 & 1,095 & 1,970 & -- & 8 & $121,159,125$ \\
\hline $\begin{array}{l}17 \\
17 \mathrm{~A}\end{array}$ & $\begin{array}{l}\text { Begunining } \\
\text { Fonal }\end{array}$ & -- & $\begin{array}{l}14.4 \\
15.4\end{array}$ & $\begin{array}{l}39.2 \\
38.4\end{array}$ & 43.9 & -- & $\begin{array}{l}110 \\
850\end{array}$ & $\begin{array}{r}20 \\
3,500\end{array}$ & $\begin{array}{l}760 \\
995\end{array}$ & $\overline{115}$ & $-\overline{380}$ & $\begin{array}{l}5 \\
11,10\end{array}$ \\
\hline $\begin{array}{l}15 \\
15 \mathrm{~A}\end{array}$ & $\begin{array}{l}\text { Beginning } \\
\text { Final }\end{array}$ & -- & $\begin{array}{l}11.0 \\
12.3\end{array}$ & $\begin{array}{l}43.0 \\
42.0\end{array}$ & $\begin{array}{l}45.0 \\
45.3\end{array}$ & -- & $\begin{array}{l}25 \\
80\end{array}$ & $\begin{array}{r}1 \\
995\end{array}$ & $\begin{array}{r}15 \\
280\end{array}$ & $\overline{80}$ & -- & $\begin{array}{l}4 \\
10,10\end{array}$ \\
\hline $\begin{array}{l}16 \\
16 \mathrm{~A}\end{array}$ & $\begin{array}{l}\text { Beginang } \\
\text { Final }\end{array}$ & - & $\begin{array}{l}11.0 \\
12.4\end{array}$ & $\begin{array}{l}43.0 \\
42.0\end{array}$ & $\begin{array}{l}45.0 \\
45.4\end{array}$ & -- & $\begin{array}{l}25 \\
60\end{array}$ & $\begin{array}{r}1 \\
855\end{array}$ & $\begin{array}{r}15 \\
270\end{array}$ & $\overline{75}$ & -- & $\begin{array}{l}4 \\
7,7\end{array}$ \\
\hline $\begin{array}{l}19 \\
19 \mathrm{~A} \\
19 \mathrm{~B} \\
19 \mathrm{C}\end{array}$ & $\begin{array}{l}\text { Beginning } \\
\text { Reused } \\
\text { Reused } \\
\text { Reused }\end{array}$ & $\begin{array}{l}-- \\
-- \\
--\end{array}$ & $\begin{array}{l}11.0 \\
11.7 \\
-- \\
12.1\end{array}$ & $\begin{array}{c}43.2 \\
42.6 \\
-- \\
41.9\end{array}$ & $\begin{array}{c}-- \\
44.2 \\
-- \\
44.3\end{array}$ & $\begin{array}{l}-- \\
- \\
- \\
-\end{array}$ & $\begin{array}{r}35 \\
226 \\
-- \\
541\end{array}$ & $\begin{array}{r}05 \\
1,400 \\
-\infty \\
4.300\end{array}$ & $\begin{array}{r}165 \\
425 \\
- \\
8,200\end{array}$ & $\begin{array}{l}-- \\
40 \\
-- \\
98\end{array}$ & $\begin{array}{c}- \\
- \\
- \\
394\end{array}$ & $\begin{array}{r}4 \\
16,16 \\
\\
\quad- \\
--\end{array}$ \\
\hline $\begin{array}{l}22 \\
22 \mathrm{~A}\end{array}$ & $\begin{array}{l}\text { Beginning } \\
\text { Reused }\end{array}$ & $\overline{-}$ & $\begin{array}{l}8.95 \\
9.95\end{array}$ & $\begin{array}{l}46.0 \\
42.1\end{array}$ & $4 \overline{5.0}$ & $\begin{array}{l}0.107 \\
0.3\end{array}$ & $\begin{array}{r}6 \\
358\end{array}$ & $\begin{array}{r}20 \\
990\end{array}$ & $\begin{array}{r}150 \\
3,200\end{array}$ & $\overline{81}$ & $-{ }_{13}$ & $\cdots$ \\
\hline 20 & $\begin{array}{l}\text { Beginning } \\
\text { Funal }\end{array}$ & $\begin{array}{l}11.0 \\
10.0\end{array}$ & $\begin{array}{l}32.0 \\
20.6\end{array}$ & - & -- & -- & $\begin{array}{r}30 \\
700\end{array}$ & $\begin{array}{r}10 \\
+2,500\end{array}$ & $\begin{array}{r}45 \\
4,200\end{array}$ & 905 & 12,400 & -- \\
\hline 21 & $\begin{array}{l}\text { Beginning } \\
\text { Final }\end{array}$ & $\begin{array}{l}11.6 \\
11.6\end{array}$ & $\begin{array}{l}31.0 \\
29.4\end{array}$ & - & $\begin{array}{c}-0 \\
52.7\end{array}$ & -- & $\begin{array}{r}10 \\
900\end{array}$ & $\begin{array}{r}20 \\
2,600\end{array}$ & $\begin{array}{r}150 \\
1,700\end{array}$ & 170 & $\overline{1,700}$ & -- \\
\hline 24 & $\begin{array}{l}\text { Beginning } \\
\text { Final }\end{array}$ & $\begin{array}{r}9.7 \\
10.7\end{array}$ & $\begin{array}{l}33.8 \\
29.0\end{array}$ & $\overrightarrow{0.14}$ & $\begin{array}{l}55.4 \\
53.8\end{array}$ & $\begin{array}{l}-- \\
-\infty\end{array}$ & $\begin{array}{r}40 \\
1,300\end{array}$ & $\begin{array}{r}270 \\
25.000\end{array}$ & $\begin{array}{r}310 \\
18,000\end{array}$ & $<20$ & $\overline{4.300}$ & - \\
\hline 18 & Beginning & 2.28 & 32.0 & 46.2 & -- & 0.69 & 10 & 45 & 205 & $-\infty$ & $-\infty$ & 5 \\
\hline $\begin{array}{l}23 \\
23 \mathrm{~A} \\
23 \mathrm{~B}\end{array}$ & $\begin{array}{l}\text { Beginning } \\
\text { Reused } \\
\text { Reused }\end{array}$ & $\begin{array}{l}2.25 \\
-- \\
1.6\end{array}$ & $\begin{array}{l}3.08 \\
-- \\
6.6\end{array}$ & $\begin{array}{l}47.2 \\
-- \\
44.9\end{array}$ & $\begin{array}{l}46.0 \\
-- \\
45.8\end{array}$ & $\begin{array}{l}0.56 \\
-- \\
0.46\end{array}$ & $\begin{array}{r}20 \\
-- \\
265\end{array}$ & ${ }_{2.200}$ & $\begin{array}{r}385 \\
- \\
4,900\end{array}$ & $\begin{array}{l}-- \\
-- \\
57\end{array}$ & 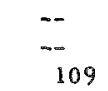 & -- \\
\hline 25 & $\begin{array}{l}\text { Beginning } \\
\text { Final }\end{array}$ & $\begin{array}{l}9.1 \\
4.3\end{array}$ & $\begin{array}{l}30.1 \\
12.4\end{array}$ & 32.6 & $\begin{array}{l}54.4 \\
49.8\end{array}$ & -- & $\begin{array}{r}25 \\
528\end{array}$ & $\begin{array}{r}60 \\
<50\end{array}$ & $\begin{array}{r}185 \\
1,300\end{array}$ & -- & - & 5 \\
\hline
\end{tabular}


To remove the more volatile impurities, about $3 \mathrm{lb}$ of HF was bled from each tank prior to use in the experiments. Residual fractions were eliminated by not using further HF after the tank was approximately two-thirds depleted.

Table A-4 shows the sulfur content of the various tanks of HF used in the studies described earlier. According to G. I. Cathers of ORNL, the quantities present in all except Tank FC 19874 are low compared to normal commercial material.

The effectiveness of the nickel desulfurizer used in the corrosion assembly was evaluated by collecting samples at various locations in the system. It was found that the residence time in the desulfurizer was too short to effect appreciable removal of sulfur. However, some removal was obtained because several nickel tubes failed from attack by sulfur at the hottest area in the furnace.

\section{Candidate Materials}

Nine different metals or alloys were evaluated in the program.

Table A-5 gives the nominal analyses of the alloys most extensively studied. The INOR -8 alloys were from Heats $\mathrm{SP}-16, \mathrm{SP}-19, \mathrm{M}-1356$, and 30-72. The specimens were usually given a heat treatment of $30 \mathrm{~min}$ at $1100 \mathrm{C}$ under a hydrogen atmosphere. The INOR -1 alloys were from Heats $Y-8195$ and $Y-8196$. Most specimens were heated for $30 \mathrm{~min}$ at $925 \mathrm{C}$ under hydrogen. 
TABLE A-4. SULFUR CONTENT OF HF

\begin{tabular}{lclc}
\hline \multicolumn{1}{c}{ Time of Sampling } & $\begin{array}{c}\text { HF Supply } \\
\text { Cylinder }\end{array}$ & Point of Sampling & $\begin{array}{c}\text { Sulfur in HF } \\
\text { ppm }\end{array}$ \\
\hline After Run 12 & A & From the tank & 66 \\
After Run 14 & B & From the tank & 86 \\
After Run 14 & B & Desulfurizer exit & 101 \\
$\begin{array}{l}\text { During Run 14 } \\
\text { After Run 17 A }\end{array}$ & B & Container exit & 134 \\
$\begin{array}{l}\text { After Run 17 A } \\
\begin{array}{l}\text { During Run 17 A } \\
\text { Aftex bleeding off } \\
\text { first 3 1b of HF } \\
\text { from new tank }\end{array}\end{array}$ & FC 11197 & From the tank & 167 \\
\hline
\end{tabular}

TABLE A-5. NOMINAL COMPOSITION OF ALLOYS EXPOSED

\begin{tabular}{lcccc}
\hline Alloy & \multicolumn{4}{c}{ Nominal Composition, w/o } \\
\cline { 2 - 5 } INOR-8 & 7 & 71 & 5 & Mo \\
INOR-1 & - & 78 & - & 16 \\
Hastelloy B & - & 65 & 5 & 20 \\
Hastelloy W & 6 & 62 & 6 & 28 \\
Inconel & 16 & 76 & 8 & 25 \\
\hline
\end{tabular}

